*ak RMIS View/Frint Document Cover Sheet tow

This document was retrieved from the Documentation and Records Manaqement (DRM) ISEARCH System. It is intended for Information only and may not be the most recent or updated version. Contact a Document Service Center (see Hanford Info for locations) if you need additional retrieval information.

Accession \#: D196047836

Document \#: SD-WM-ER-537

Title/Desc:

DESIGN \& OPERATIONS REVIEW OF CORE SAMPLING TRUCKS \& ASSOCIATED EQUIPMENT

Pages: 52 


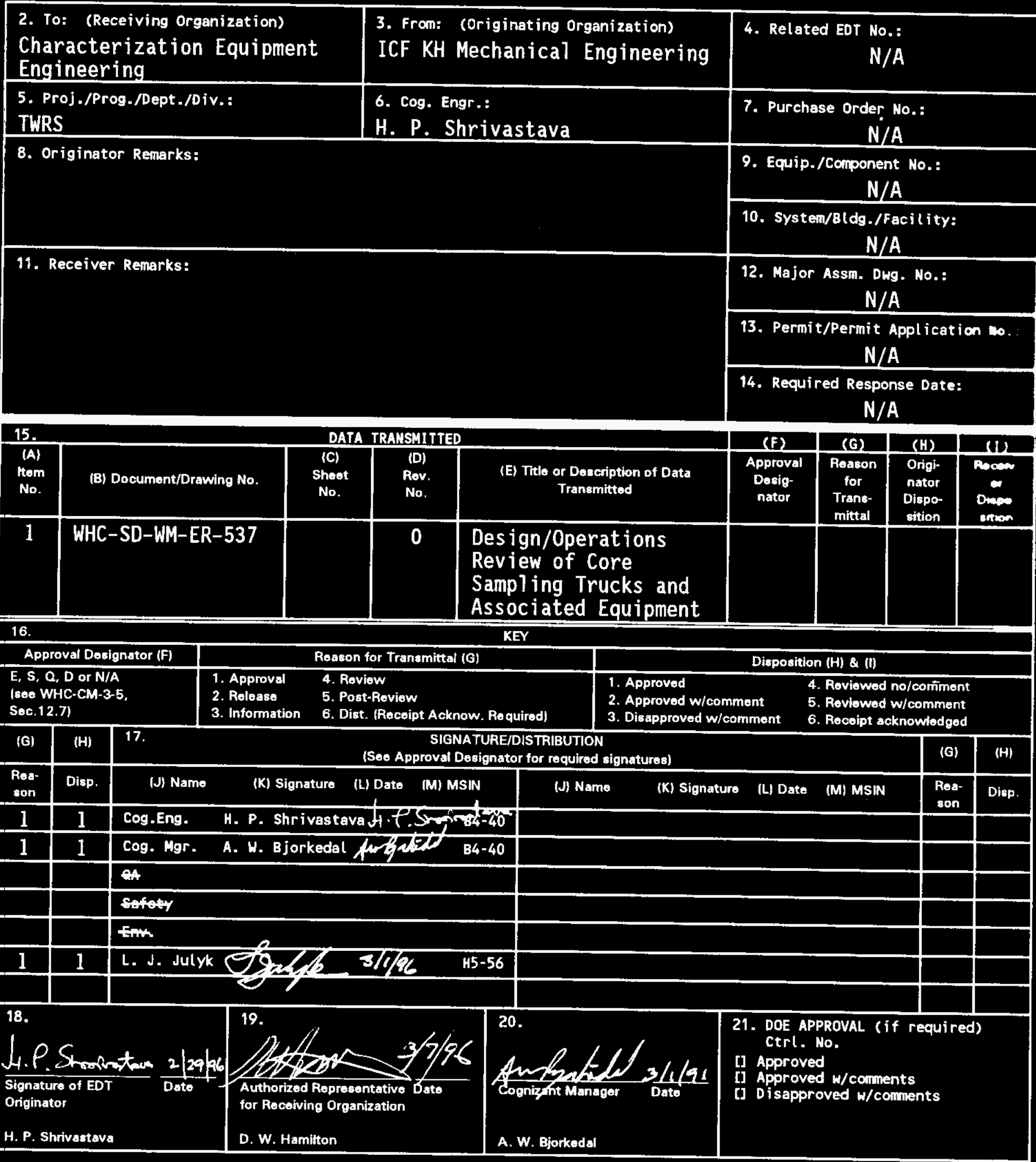

BD-7400-172-2 (04/94) GEF097 


\title{
DESIGN/OPERATIONS REVIEW OF CORE SAMPLING TRUCKS AND ASSOCIATED EQUIPMENT
}

H. P. Shrivastava.

ICF Kaiser Hanford Company, Richland, WA 99352

U.S. Department of Energy Contract DE-AC06-87RL10930

\author{
EDT/ECN: 615123 UC: 2070 \\ Org Code: $57400 \quad$ Charge Code: PlT901 \\ B\&R Code: EW3120074 Total Pages: 49
}

Key Words: Waste Characterization, Core Sampling

Abstract: A systematic review of the design and operations of the core sampling trucks was commissioned by Characterization Equipment Engineering of the Westinghouse Hanford Company in October 1995. The review team reviewed the design documents, specifications, operating procedure, training manuals and safety analysis reports. The review process, findings and corrective actions are summarized in this supporting document.

TRADEMARK DISCLAIMER. Reference herein to any specific commercial product, process, or service by trade nane, tradenark, manufacturer, or otherwise, does not necessarily constitute or imply its endorsement, recomendation, or favoring by the United States Government or any agency thereof or its contractors or subcontractors.

Printed in the United States of America. To obtain copies of this document, contact: WHC/BCS Document Control Services, P.0. Box 1970, Mailstop 16-08, Richtand WA 99352, Phone (509) 372-2420; Fax (509) 376-4989.
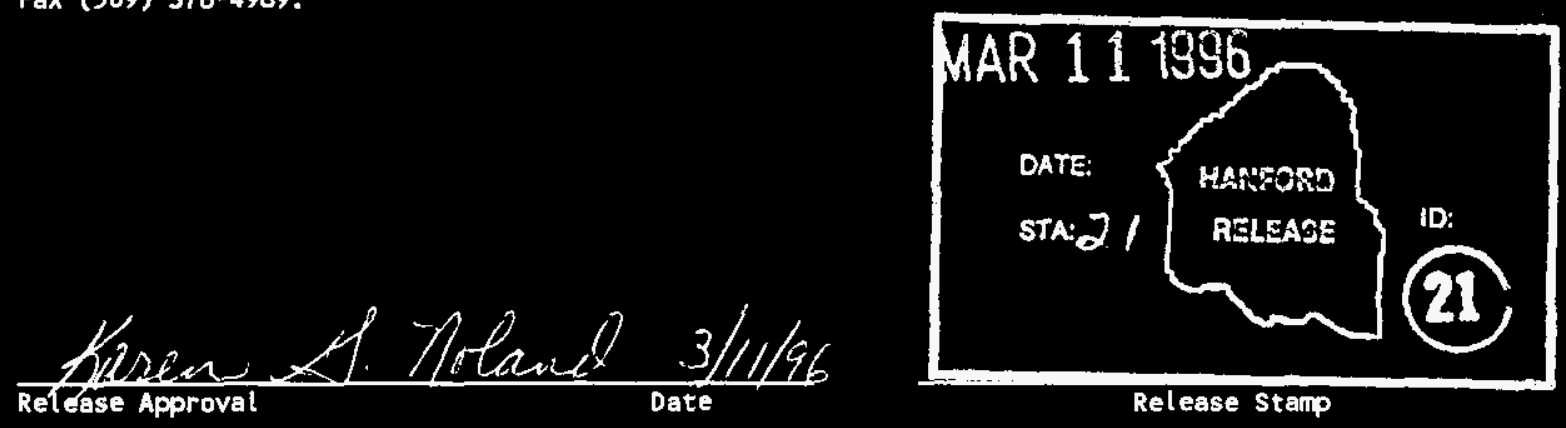

\section{Approved for Public Release}




\title{
DESIGN/OPERATIONS REVIEW OF CORE SAMPLING TRUCKS AND ASSOCIATED EQUIPMENT
}

\author{
Prepared for \\ Westinghouse Hanford Company \\ January 1996
}

H. P. Shrivastava

V. R. Enderl in

B. M. Koons

Prepared by

ICF Kaiser Hanford Company

Richland, Washington 


\section{DESIGN/OPERATIONS REVIEW OF CORE SAMPLING TRUCKS AND ASSOCIATED EQUIPMENT}

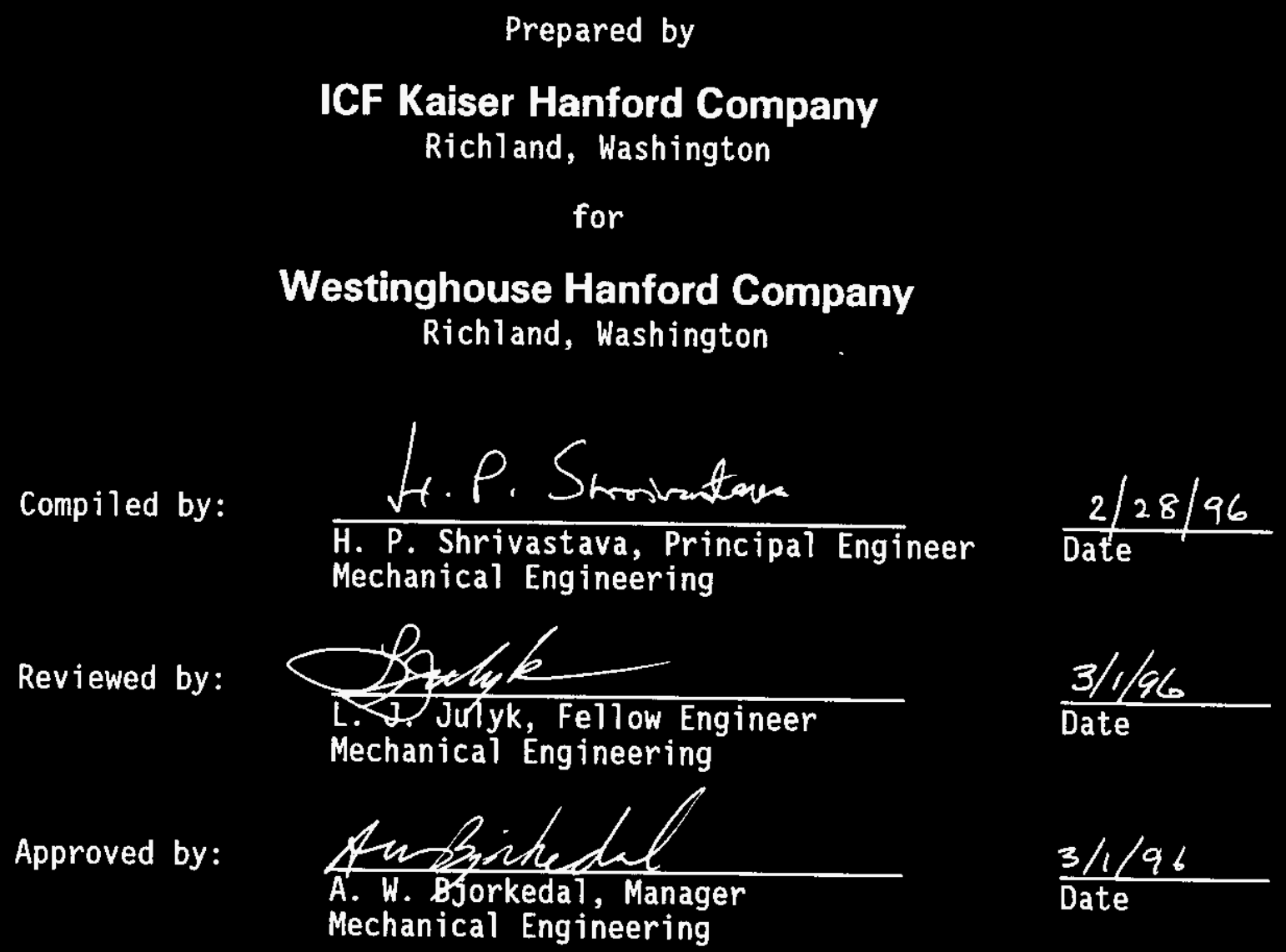

Westinghouse Hanford Company

Approved by:
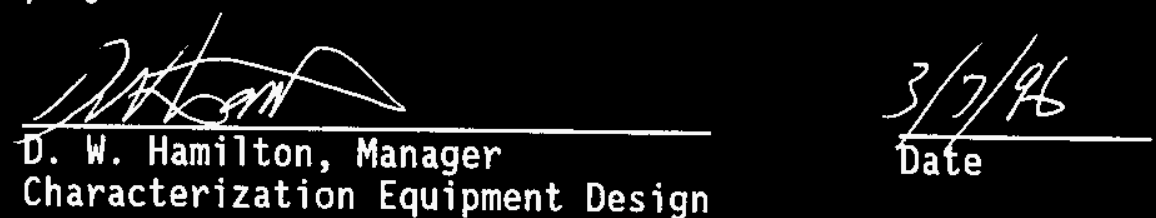
WHC-SD-WM-ER-537

Rev. 0

\section{INDEPENDENT REVIEN}

Document Reviewed Design/Operations Review of Core Sampling Trucks and Associated Equipment

Author H. P. Shrivastava Report No. WHC-SD-WM-ER-537 EDT No. 6/5/23

The subject document has been reviewed by the undersigned. The reviewer reviewed and verified the following items as applicable [EP.4.1].

- Engineering Specification

- Design Input

- Basic Assumption

- Approach/Design Methodology

- Related Information

- Conclusion/Result Interpretation
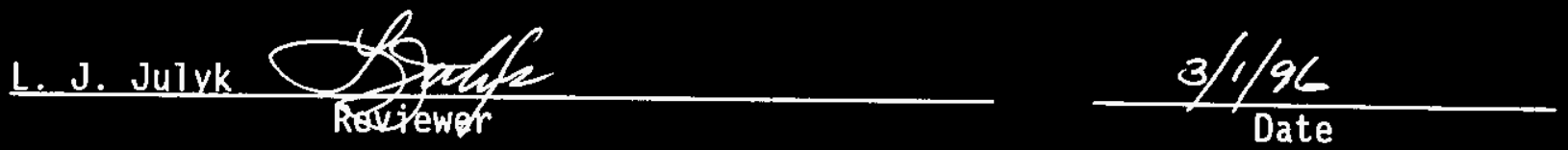
WHC-SD-WM-ER-537

Rev. 0

\section{CONTENTS}

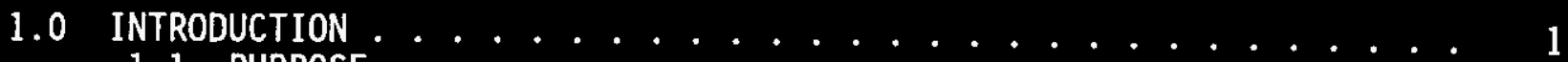

1.1 PURPOSE

1.2 BACKGROUND

1.3 SCOPE

1.4 REVIEW PROCESS

2.0 SUMMARY

3.0 DESIGN/OPERATIONS REVIEW . . . . . . . . . . . 9

3.1 STRUCTURAL AND STRESS ANALYSES DESIGN REVIEW ........ 9

3.1.1 Jacks and Lower Frame .............. 9

3.1 .2 Rotating Platform ............... 10

3.1.3 Dril1 Head Service Platform .......... 10

3.1.4 Shielded Receiver Lifting Frame . . . . . . . . 11

3.1.5 Grapple Hoist Mount ing Support Assembiy $\ldots . . .11$

3.1.6 Sampler Hoist and Grapple Hoist Housings . . . . . 12

3.1.7 Grapple Hoist Cable Pulley Shaft . . . . . . . . 12

3.1 .8 Dril1 String

3.2 OPERATING PROCEDURE REVIEW . . . . . . . . . . . 13

3.3 OPERATOR TRAINING

3.4 MECHANICAL SYSTEMS/COMPONENTS FAILURE MODE ANALYSIS $\cdots . .15$

3.4.1 Core Sample Tasks ............... 16

3.4 .2 Critical Systems . . . . . . . . . . . . . 17

3.4 .3 Non-critical Systems . . . . . . . . . . . . 17

3.4 .4 Critical Components .............. 18

3.4 .5 General Failure Reduction Actions . . . . . . . 23

3.5 PREVENTATIVE MAINTENANCE ......................... 24

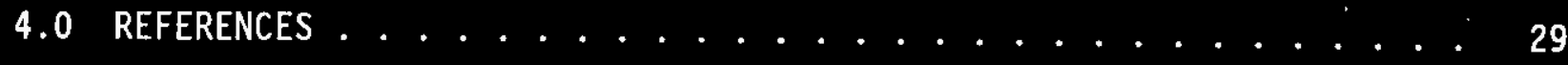

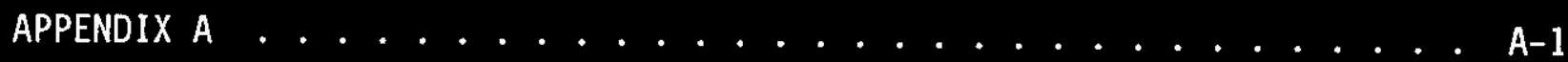


WHC-SD-WM-ER-537

Rev. 0

\section{TABLES}

1. Core Sampling Tasks and System Criticality ........... 25

2. Critical Systems ................. 26

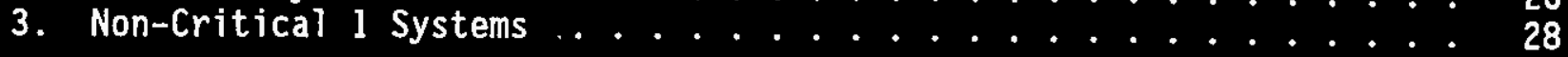


WHC-SD-WM-ER-537

Rev. 0

\section{DESIEN/OPERATIONS REVIEW OF CORE SAMPLING TRUCKS \\ AND ASSOCIATED EQUIPMENT}

\subsection{INTRODUCTION}

\subsection{PURPOSE}

A systematic review of the design and operations of the core sampling trucks was commissioned by Characterization Equipment Engineering Department of the Westinghouse Hanford Company (WHC) in October 1995 to identify potential problems that may cause complete system shutdown and/or unsafe operation of the trucks. The review was prompted by the frequent problems and less-than-desirable availability of the trucks. A task team was formed to review the design of the trucks, from concept through the latest evolution, and operation of the trucks, from training through operations. The team was to also recommend improvements and corrections for any identified problems.

\subsection{BACKGROUND}

The core sampling trucks were designed and built for use at the Hanford Site and are used to obtain stratified waste samples from the single- and double-shell waste tanks for waste characterization to support the tank waste remediation efforts. Four trucks are currently available. Truck 1 was acquired first and operates only in the push mode to obtain samples. Truck 2 is an improved version of Truck 1 ; the lessons learned through the operation of Truck 1 were implemented into the Truck 2 design. In addition to the push mode, Truck 2 can be operated in the rotary mode for sampling harder saltcake waste types. Trucks 3 and 4 are similar to Truck 2. Some enhancements were incorporated in their design based on operational experience gained from Truck 2 but for the most part they replicate the Truck 2 design. The primary objective in acquiring Trucks 3 and 4 was to expedite backup capability thus increasing overall sampling availability. Because of this any moderate to major design changes were sacrificed to this primary objective.

As the evolution of the core sampling truck design progressed, several reviews were performed. Operational availability became critical to support the core sampling schedule and Trucks 1 and 2 had not reached their expected availability level due to frequent breakdowns. There were platform failures, drill string failures, and problems with hydraulic and electrical systems. Many reviews of the design, processes and procedures, operations, and safety provisions were conducted for Truck 2.

The latest previous review was completed in February 1995 and is documented in Jenkins 1995 . The review team headed by W. W. Jenkins was formed to identify potential unknown problems and recommend corrective actions to eliminate the problems in an affordable and timely manner. The review focused on operational availability of Truck 2 and was limited to hardware, software, controls, and operational procedures. The review team concluded that the systems reflect a high degree of consideration for the safety of operating personnel and require no major redesign. However, several recommendations were made that include minor design changes and changes in the 
operating methods to improve the availability of the core sampling trucks. Trucks 3 and 4 were being fabricated during the Jenkins review and, therefore, were not specifically reviewed.

The U.S. Department of Energy (DOE), Richland Field Office (RL), conducted a readiness review for Truck 2 (DOE-RL 1994) and for Trucks 3 and 4 (DOE-RL 1995). The deficiencies found in these reviews were corrected before the trucks were deployed in the field.

Stress analyses of several key structural elements have been performed to establish design adequacies. The stress analyses, based on static loading, identified some undersized welds and structural members. As a result of the analyses recommendations, modifications were made to the welds and structural members.

Currently, all four trucks are being used to obtain tank waste samples. Improvements in any given truck's availability is desired but not essential to meet the core sampling schedule because of the backup provided by the multitruck system. Therefore, the adoption of improvements identified by the various reviews and the resolution of operational problems have typically been moved to a convenient time to reduce the truck downtime to a minimum.

The trucks are operated on all three shifts throughout the year. A person-in-charge (PIC), a cognizant engineer, operators, and a quality control technician are the main participants with support from a health physics technician, an industrial health and safety technician, and a pipe fitter. A tank farm plant operating procedure (WHC 1995) contains the steps for preparing to sample, sampling, and returning the tank to a stabilized state on completion of sampling activities. The people responsible for this procedure modify it frequently as deemed necessary. The operator's training manual (WHC 1994) contains the general description and operation of the trucks.

\subsection{SCOPE}

The main focus of this review is on Trucks 3 and 4 . The review team is chartered with the task of reviewing the design of the hardware, control, and hydraulic systems; the operator's training material; and the in-field operations and operating procedures. Deficiencies, if any, related to these items are to be identified and appropriate corrective actions are to be outlined. This review will not address the electrical systems directly, except where their failure might lead to a mechanical failure.

\subsection{REVIEN PROCESS}

During the design review of the core sampling trucks, the documentation that is common to Trucks 2, 3, and 4 and that is specifically related to the design of Trucks 3 and 4 have been reviewed by the team. These documents include design specifications, fabrication drawings, structural evaluations, previous design and readiness reviews, safety analysis, training manuals, and the operating procedure. The majority of supporting stress analyses were carried out for Truck 2. Because Trucks 3 and 4 are essentially identical to Truck 2, the supporting stress analyses for Truck 2 are directly applicable to 
Trucks 3 and 4 . The purpose of this review was two-fold. The documentation review was necessary to familiarize the review team members with the design requirements and the truck design. Secondly, the review was an essential first step to the identification of any potential problem areas in the design.

Upon completion of the documentation review, the team viewed a short video prepared by Westinghouse Hanford Company (WHC) and spoke with the operations staff to gather information about the actual operation of the trucks. The problem and actions logs maintained by WHC were also reviewed to identify recurring problems and trends in operations, and to examine the appropriateness of the corrective actions taken to fix these problems. This operations review helped find potential procedural ambiguities and operational problems experienced by the operations staff.

The team members also reviewed the operator training manuals to assess the training adequacy against the problem and action logs. The training was also assessed for consistency and sufficient content with reference to the operating procedures.

The last step of the review process was to perform a hazard/failure analysis. Based upon the data collected as outlined above and summarized in Appendix A, a failure modes, effects, and criticality analys is (FMECA) was performed to identify components critical to obtaining a sample and potential sources of problems in the design, training, or operations that would interfere with sampling. The process used in the FMECA and the results are included in Section 3 . 
WHC-SD-WM-ER-537

Rev. 0

\subsection{SUMMARY}

The review team reviewed the design documents, specifications, operating procedure, training manuals, and safety analysis as described in Sections 1.2 and 1.3. Although there were no inevitable impending catastrophic failures found, there were some findings that could cause unscheduled down time if they were not addressed in a timely manner. These findings and the corrective actions are summarized below and have been grouped into categories that affect design, operations, training, and maintenance. The main components and operation of the truck are described in Appendix A.

Design

1. The design basis information for the rotary mode core sampling truck are given in Farris 1993, Smalley 1993, and Francis 1994. Farris 1993 provides development criteria for the rotary mode, universal sampler and bit, and the normal paraffin hydrocarbon (NPH) el imination systems.

Smalley 1993 provides the specification for the rotary mode core sample truck and Francis 1994 provides the rotary mode sampling system acquisition information. However, there appears to be an absence of a single formal functional design criteria document that adequately specifies the design loads and evaluation criteria for acceptance. This is obvious from the varying load values used in the qualifying stress analyses. For example, the analys is of the shielded receiver lifting frame has been performed using truck accelerations which are significantly smaller than those used for the other components.

Corrective Action: The design loads, applicable codes and standards, and the acceptance criteria should either be included in Smalley 1993-or in a separate design requirements document.

2. The major structural components have not been evaluated for the wind load effects. The trucks have 1 imited capacity to resist the wind loads as indicated by the structural analyses for the front, rear, and center jack assemblies which indicate that the jacks have minimal horizontal load capacity.

The operating procedure requires the work to stop if the person-incharge determines that the wind velocity is unsafe but does not specify what velocity is unsafe.

Corrective Action: The effect of wind loading when the truck is deployed for sampling should be evaluated and the critical wind speed beyond which the trucks are not allowed to operate should be established. The wind speed should be included in the operating procedure.

3. The structural evaluations were based on the American Institute of Steel Construction (AISC) stress allowables for building structures in which fatigue failure is not a concern. All components on the trucks are subjected to reversible loading (when accelerating and braking) during transportation that can cause fatigue. The AISC also provides allowable 
stress ranges for loadings that are cyclic. Under the AISC rules, consideration of fatigue failure is required only if the number of stress cycles exceeds 20,000 .

Corrective Action: The design should be based on at least 20,000 stress cycles resulting from the cyclic transportation loads which occur several times each time the truck is moved from one tank farm to the other. This figure may be conservative because the trucks are expected to take 3 core samples at each of the 177 tanks which equates to 177 tank-to-tank moves at a specified speed of $15 \mathrm{mph}$ and three slower maneuvers around each tank and the total number of such moves is shared among 4 trucks. However, the actual number of stress cycles for each truck is difficult to forecast because it may depend on many factors including driving habits.

Using the stress range allowables for 20,000 cycles from the AISC Manual and the existing stress analyses, the critical welds and bolted joints should be identified and included in a preventive maintenance program for an inspection on a regular basis.

4. The Safety Analysis Report (Milliken 1995) limits the drill string down force to 3,600 $1 \mathrm{bf}$. The operating procedure, on the other hand, allows the down force, in the push mode, to be up to 5,300 1 bf which is based on the minimum load required to cause penetration of the tank bottom plate by the drill string. These limits are too high and can cause permanent damage to the drill string.

Corrective Action: The maximum axial load that can be sustained by the drill string should be established as a function of the length of the drill string deployed. The evaluation should use conservative boundary conditions and should also account for initial curvature of the drill string resulting from angled penetration or wobbling when the drill bit contacts the waste surface. The database generated will help the cognizant engineer determine how high the axial load can be applied.

5. Several oil leaks have been reported for the hydraulic system. The current design utilizes many hoses and threaded fittings. To minimize hydraulic leaks, the number of hoses and fittings should be reduced if possible.

Corrective Action: The number of hoses and fittings can be reduced using a custom built manifold without any change in the current hydraulic logic. The cost of such a manifold is estimated at approximately $\$ 5,000$ which excludes installation costs.

6. The hydraulic jacks have failed due to fluid leakage. This occurred during the pre-operational testing phase when the truck was maintained on the jacks for an extended period of time and was exposed to changing environmental conditions. The failure occurred because of changes in temperature which caused excess pressure resulting in seal failure.

Corrective Action: An accumulator could be used to maintain constant pressure in the system. A single accumulator with a one-gallon capacity should be sufficient. 


\section{Operations}

Without experiencing the training that the operators have prior to using the operating procedure, an objective evaluation of the usefulness of the operating procedure was not possible. Because the procedure is frequently modified, its usefulness was left to be determined by those using it. The review team, therefore, focused more on discrepancies between the procedure and the design documents and problem $\mathrm{log}$.

1. Section 5.3 of the operating procedure suggests that the drill string downward force should be 1 imited to less than 1,000 lbf in both rotary and push modes of operation. Table 3 of the procedure, however, specifies 1,170 lbf as the highest force that can be applied in the rotary mode of operation and the maximum force goes up to 5,300 1bf for the push mode operation. The later value is derived from the consideration of the tank bottom penetration and is too high from a drill string failure viewpoint.

Corrective Action: The operating procedure should be revised to incorporate the down force limit obtained from the buckling analyses of the drill string.

2. Stabilization (Section 5.11) of the truck following sampling operations does not include lowering the truck off the leveling and stabilizing jacks.

Corrective Action: The operating procedure should be revised to require that the truck be lowered off the jacks when it is unattended and not expected to be operating for an extended period of time.

3. In certain steps of the operating procedure, the operator repeats a sequence when success is not achieved in the first attempt. In some cases, this approach to failures has caused damage to components.

Corrective Action: A trouble shooting guide for in-field use would reduce downtime by eliminating the easy to find, quick to fix problems first before more serious damage occurs. A guide could al so decrease potential damage by identifying possible causes of malfunctions and the steps to take to avoid causing damage until the specific cause is identified. The FMECA on this task and the problem $10 \mathrm{~g}$ are significant starting points for developing such a guide.

4. Operating Procedure 5.2.1 requires the operator to perform daily inspections according to the Daily Core Sample/Inspection Data Sheet 5 to check the condition or operation of systems on the truck at the beginning and end of each shift. The current order of check points has the platform movement checked before drill string disconnection is verified. If followed blindly, this order could cause serious damage to the tank penetration as well as the drill string and truck systems.

Corrective Action: The checklist should be reordered so that the drill string disconnection is verified prior to checking the platform movement systems. 
WHC-SD-WM-ER-537

Rev. 0

\section{Training}

The team members reviewed the training manuals and found them descriptive enough to understand the functions of different elements of the truck operations. However, the evaluation of the training manuals is only limited to checking consistency between the operating procedure, training manuals, and design documents. The team members did not get the classroom training and did not operate the truck.

1. The current design of the universal sampler is slightly different from the one described in the manual.

Corrective Action: Revise the manual to reflect the latest design used for the universal sampler.

2. In discussions with truck personnel, training was said to be minimal in hands-on training prior to actual sampling operations. Although the manual clearly explains the functions of the systems and the operating procedure provides most of the steps needed to perform the tasks, handson experience is essential for performing those tasks effectively. Only through hands-on experience with guidance from an experienced operator can the operator get a feel for the correct operation of the truck.

Corrective Action: Operators new to the truck should have more extensive hands-on training before being certified for solo operation.

3. The training manual gives the impression that all platform rotation is prevented if the interlocks that prevent rotation when the shielded receiver or drill rig is down or the traversing platform is not centered are active. The actual arrangement is that only fast rotation is locked out and slow rotation is still possible.

Corrective Action: The manual should be revised to reflect the actual operation. The current description in the manual can give a new operator a false sense of security, leading to the assumption that the shielded receiver, drill rig, and traversing platform are correctly positioned for rotation.

4. The training manual does not discuss a hydraulic bypass valve associated with Trucks 3 and 4.

Corrective Action: A discussion of the hydraulic bypass valves on Trucks 3 and 4 should be added to the training manuals to explain their function and operation.

\section{Maintenance}

1. In the harsh environment of the tank farms, debris can quickiy build up and cause sticking which interferes with correct operation of the interlocks and limit switches. Their failure is unpredictable and not obvious without some investigation.

Corrective Action: The interlock/limit switches should be cleaned, tested, and replaced on a regular basis. 
2. The hydraulic system is key to 3 of the 4 critical systems of the truck. Failure of the hydraulic system means no sampling at all. Leaks in the hydraulic system can lead to slipping hazards and loss of hydraulic fluid and pressure.

Corrective Action: The components of the hydraulic system should undergo routine maintenance. Fittings should be checked for tightness, and actuator seals should be checked for leaks and repaired if required. If a leak in the hydraulic system is suspected due to an over-tightened fitting, the fitting must be replaced. The fittings should be tightened using ordinary end wrenches without cheater bars or extensions.

Filters should be replaced regularly and fluid should be changed or run through a filter assembly for cleaning.

3. Components in a hydraulic system can become dry during long idle periods as the oil settles in the system.

Corrective Action: One very important maintenance item is to exercise the hydraulic components if they are not in use for extended periods. Actuators should be run through their stroke two or three times, the directional control valves should be cycled, and pumps and motors should be operated after two months of idle time.

4. As suggested in the stress reports, some of the welds have stresses close to allowables and in some cases exceed the allowables.

Corrective Action: Suspect and borderline allowable welds should be inspected on a regular basis.

5. Al1 high risk systems associated with the trucks and the weld inspection suggested in item 4 above should be included in the preventative maintenance program. 
WHC-SD-WM-ER-537

Rev. 0

\subsection{DESIGN/OPERATIONS REVIEW}

The review team, as stated earlier, had a charter to review design documents, stress analyses, operating procedures, and previous safety reviews, and to perform a failure mode analysis to determine the critical truck component failures which can cause major operational problems, property damage, or personne? injury.

The available design/operations documents, training materials, and other design reviews were reviewed first. Then a detailed component by component failure mode analysis was performed. The results of these reviews/analyses are summarized below.

\subsection{STRUCTURAL AND STRESS ANALYSES DESIGN REVIEN}

Although no structural components were evaluated for their structural integrity during the design phase, many of them were evaluated later.

Rollover analyses were performed for Truck 2 ( $\mathrm{Ziada} 1994 \mathrm{~b}$ ) as well as for Trucks 3 and 4 (Vollert and Hundal 1995) to determine the maximum permissible truck speed.

Sections 3.1 .1 to 3.1 .8 briefly describe the stress analyses performed to evaluate the structural adequacy of some of the components. These sections also provide the review team's comments. The majority of the structural analyses are for Truck 2. However, because Trucks 3 and 4 are similar to Truck 2, these reports were assumed to be applicable to Trucks 3 and 4 .

\subsubsection{Jacks and Lower Frame}

Ziada 1995 analyzes the jacks, the lower frame assembly and connections to the truck chassis, the bolted connections for the bearing plate assembly, the traverse slide brackets, and the mounting of the traverse hydraulic rams for Truck 2. The analyses considered the deadweight of the components. Some bolts were changed to larger sizes as a result of this analysis. The analysis also indicates that the horizontal load capacity of the jacks is not more than $5 \%$ of the vertical load capacity.

The jack assemblies for Trucks 3 and 4 have been analyzed in Vollert \& Hundal 1995. This analysis also indicates that the jacks have a limited capacity for horizontal loads.

\section{Review Comment}

Wind loading was not considered in the above analyses of the jack assemblies. In view of the small horizontal load carrying capacity of the jacks, the deployment of trucks in the field during high wind may result in irreparable damage to the trucks and possible personnel injury. Although the operating procedure prohibits operation of the truck when wind velocity is expected to be high, it does not define which wind speed should be considered high. Reportedly, it was previously established by procedure at $15 \mathrm{mph}$ but 
Rev. 0

was subsequently changed to allow the Operations Person-in-Charge to decide when wind speed is too high. The review team recommends that an analysis be performed to determine the critical wind speed.

\subsubsection{Rotating Platform}

An analysis of the rotating platform in the vicinity of the crane was performed in Ziada 1994a for an abnormal load of 2,000 1bf. The crane once lifted a load that was significantly higher than the 500 lbf load limit and because of this some welds cracked. Design changes were made to strengthen the platform and Ziada 1994a supports those weld modifications. For the 2,000 lbf crane load, however, some beam-to-channel welds have only a $1 \%$ margin.

\section{Review Comment}

Although design changes were made to the platform to allow the crane to 1 ift up to 2,000 $1 \mathrm{bf}$, the operating procedure, and markings on the crane itself limit the load to $500 \mathrm{lbf}$. Should this limit be increased to 2,000 lbf, the platform beam-to-channel welds should be added to the preventative maintenance program.

\subsubsection{Drill Head Service Platform}

Ziada 1995 analyzed the drill head service platform assembly for Truck 2. This platform was analyzed for its own weight and the weights of the components supported by this platform. Other loads considered are 3-g longitudinal (truck moving forward), $1-g$ vertical (downward), and 2-g lateral accelerations which represent the maximum accelerations of the truck when it is driven from one site to the other. Although not documented, the review team was told that these accelerations are applicable if the truck is driven at a speed of $55 \mathrm{mph}$.

The acceptance criteria were from the American Institute of Steel Construction (AISC 1989) manual. The analysis recommended that some of the bolts be changed to larger sizes. However, the end plate was shown to have only a $10 \mathrm{lbf} / \mathrm{in}^{2}$ margin against an allowable stress of $30,6661 \mathrm{bf} / \mathrm{in}^{2}$. At least one weld type has a margin of only $1.5 \%$.

\section{Review Comment}

The calculated stresses were evaluated against the allowables provided by AISC 1989. Although AISC 1989 has allowables for stresses caused by reversible loads, the stress allowables used in the above calculations are for building structures for which fatigue failure caused by cyclic loading is not a concern. Transportation loads, however, are cyclic; therefore the resulting stress ranges should have been evaluated against the allowable stress range.

If a reduced allowable stress is used, some of the welds now shown to be acceptable will be over stressed. Failure of these welds, especially during transport, can cause significant equipment damage. 


\subsubsection{Shielded Receiver Lifting Frame}

The shielded receiver 1 ifting frame for Truck 2 was analyzed in $\mathrm{Ziada} 1994 \mathrm{C}$ for the deadweight and transportation acceleration loads. The accelerations used in this report are significantly lower $(0.43-g$ longitudinal, $0.37-g$ lateral, and $0.18-g$ vertical) than those used in the analyses discussed above and were taken from the rollover analyses performed in $\mathrm{Ziada}$ 1994b. The results indicated that even for the low accelerations used, many of the members and welds needed strengthening.

The shielded receiver lifting frame assemblies for Trucks 3 and 4 have been analyzed in Vollert \& Hundal 1995. The shielded receiver lifting frame is analyzed for the deadweight and transportation loading. The transportation accelerations used are from Ziada $1994 \mathrm{~b}$ and are significantly lower than those used in Koehler 1992 and Ziada 1995. For these lower transportation loads, some of the weld joints have stresses nearly equal to the AISC allowable. Similar conclusions were noted in Ziada 1994c which analyzed the shielded receiver 1 ifting frame for Truck 2 .

\section{Review Comment}

1. The stress analyses of the shielded receiver 1 ifting frames for Trucks 2, 3, and 4 for the transportation loading consider $0.43-g$ longitudinal, $0.37-g$ lateral, and $0.18-g$ vertical accelerations. The drill head service platform and the grapple hoist mounting support assembly have been analyzed for 3-g longitudinal, 2-g lateral, and $1-g$ vertical accelerations. It is not clear which accelerations are more appropriate, but the lifting frames are not adequate to sustain the higher acceleration loadings because some of the members and welds had to be modified to meet the AISC stress allowables when the analyses considered the lower values of the transportation accelerations.

Because the transportation loadings are critical, the accelerations to be considered in design should be established and consistently applied to all critical structural components. Failure of the welds during transport can cause considerable equipment damage.

2. As stated in Section 3.1.3, the use of AISC stress allowables for static loads may not be appropriate for the transportation loads applied to the shielded receiver lifting frame.

\subsubsection{Grapple Hoist Mounting Support Assembly}

Koehler 1992 documents the stress analyses for the grapple hoist mounting support assembly which is a structural steel frame bolted to the drill head service platform. The frame supports the grapple hoist and associated electric drive motor, gear box, and counter.

The frame was analyzed for its own weight and the weights of the components it supports. Transportation accelerations of 3,2 , and $1 \mathrm{~g}$ were applied in the longitudinal, lateral, and vertical directions, respectively. Negative values of lateral and longitudinal accelerations were also considered. The resulting stresses were compared with the American Institute 
of Steel Construction (AISC 1989) stress allowables. One location was found to be over stressed and this report recommended a modification to a baseplate gusset. The design safety margin based on the evaluation criteria used is 13$20 \%$.

\section{Review Comments}

As pointed out in Sections 3.1.3 and 3.1.4, the use of the AISC stress a) lowables for the static loading is not appropriate for the transportation loads which are cyclic in nature. Failure during transport can cause significant damage.

\subsubsection{Sampler Hoist and Grapple Hoist Housings}

The sampler hoist housing and the grapple hoist housing which are rectangular cross-section boxes have been analyzed in Rezvani 1992 and Rezvani 1993, respectively. The sampler hoist housing is analyzed for a normal operation pressure of $37 \mathrm{lbf} / \mathrm{in}^{2}$ and a design pressure of $55 \mathrm{lbf} / \mathrm{in}^{2}$. The normal and design pressures considered in the grapple hoist housing analys is are 110 and $165 \mathrm{lbf} / \mathrm{in}^{2}$. These analyses are performed in accordance with the American Society of Mechanical Engineers (ASME) Code, Section VIII, Division 1. Using Section VIII, Division 2 criteria, these analyses also demonstrate that fatigue failure is not a concern.

\section{Review Comment}

Although in the case of the grapple hoist housing only a small design safety margin on the primary membrane stress exists, these analyses seem to be adequate.

\subsubsection{Grapple Hoist Cable Pulley Shaft}

Ziada 1995 evaluates the cable pulley shaft of the grapple hoist assembly. The evaluation is based on a shock loading factor of 2.0 and a stress concentration factor of 3.0 in the keyway region. This analys is was performed after the shear pins of the cable drum with the original $\frac{1}{2}-$ in. shaft failed twice during the operating tests. The analysis recommended a 1-in. diameter shaft with two $\frac{1}{4}-$ in. diameter shear pins.

\section{Review Comment}

The stress evaluation of the grapple hoist cable pulley shaft is adequate.

\subsubsection{Drill String}

Ziada 1994d provided data on the recommended magnitude of the downforce on the drill string dependent on the drill speed. The document recommends that the axial force should not exceed $5001 \mathrm{bf}$ when the end of the drill string is still free to move laterally (prior to the bit entering the solid waste) and 1,000 lbf when the end becomes fixed laterally in the hard waste (after penetration of the waste). These 1 imits prevent the drill string from 
buckling in the rotary mode of operation. For the push mode, Ziada 1995 shows a lower bound buckling load between 1,500 and 1,000 1bf for drill string lengths varying between 40 and $50 \mathrm{ft}$. These 1 imits are much lower than those listed in the operating procedure (WHC 1995).

\section{Review Comment}

The drill string critical buckling load provided in the Safety Analysis Report (Milliken 1995) seems to be excessively high compared to the other analyses. For the realistic drill string length and the boundary conditions, Ziada 1995 provides more appropriate limiting axial loads. These 1 imits should supersede those currently in the operating procedure, which reflect those limits in Milliken 1995. Buckling of the drill string can interfere with its recovery from the tank penetration.

\subsection{OPERATING PROCEDURE REVIEW}

The plant operating procedure, T0-080-056 (WHC 1995), was reviewed to determine its adequacy for the truck operation. This procedure applies to rotary mode core sampling using trucks 2,3 , and 4 .

The procedure seems consistent with the description of the operation provided by the training manuals. However, without actual training and handson operation of the trucks, the review team cannot fully judge the adequacy of the operating procedures. In discussions with truck personnel, the team found that the procedure is frequently changed. The changes are initiated by those using the procedure and those who resolve problems encountered during operations. If used judiciously, this approach to improving the procedure is effective.

In the general review of the procedure, the review team noted a discrepancy in the drill downward force specification. If this downward force is too high, a drill string failure will result. Section 5.3 of the operating procedure provides a 7 ist of suggested drilling parameters. In accordance with this list, the downward force should be less than 1,000 $1 \mathrm{bf}$ in both rotary and push modes of operation. Table 3 of the procedure, however, specifies 1,1701 bf as the highest value which can be applied in the rotary mode of operation and the maximum value goes up to 5,300 lbf for the push mode operation. The rotary mode value is consistent with the safety analys is report (Milliken 1995). However, the safety analys is report provides two limiting numbers in the push mode: 5,300 lbf to preclude penetration of the tank bottom and 3,600 $1 \mathrm{bf}$ for the buckling of the drill string. The operating procedure obviously chose the higher value. The 3,600 1bf buckling 1 imit itself seems to be too high which was probably obtained for the most favorable boundary conditions. The buckling analyses performed later (Ziada 1995) show smaller axial load allowables.

Paragraph 5.3.6 of the operating procedure allows the platform to be traversed or rotated slightly, at the Cognizant Engineer's discretion, to permit angled penetration of waste. When this happens, the allowable axial force should be reduced further. To prevent drill string failure due to excessively high axial load, the Cognizant Engineer's decision should be based 
on a set of axial load allowables that are based on conservative boundary conditions and that account for initial curvature of the drill string.

Section 5.11, "Place Rotary Truck into Stabilized Mode" 1 ists the conditions in which systems on the truck should be left when ceasing operations. The list does not include lowering the truck off the leveling and stabilizing jacks. The jacks have no compensation for expansion or contraction of the fluid and they have failed under temperature changes. The lowering of trucks from the jacks should be added to the list for stabilization.

The operating procedure directs the operator to repeat attempts to attach the remote latch unit to the sampler. Repeated attempts are also used to separate the pintle rod from the sampler. Other sections refer the operator to the Cognizant Engineer or Person-In-Charge if a sampler is not lowered to an anticipated level. In these situations, failure to achieve the desired result has some cause, some with multiple possibilities. If a wrong assumption is made regarding the cause of the failure, components can be damaged by repeated attempts. A fail-safe approach to identifying the failure specifically or at least eliminating the damage would be to incorporate resulting possibilities into the procedure where practical.

Data Sheet 5, Daily Core Sample/Inspection, of the operating procedure is a list of items to be checked at the beginning and end of each shift. If the sequence is followed from top to bottom, the platform movement is checked before disconnection of the drill string from the truck is confirmed. If the drill string was actually attached while the platform movement was checked, the tank penetration and truck would be damaged.

\subsection{OPERATOR TRAINING}

The training manuals provided to the team were used to supplement the familiarization of the team members with the operation of the truck. An objective evaluation of the adequacy of the manuals to educate someone in the actual operation of a truck was not possible. The team members never attempted to operate a truck. Evaluation of the training manuals is, therefore, limited to consistency between the operating procedure and the training manuals, to how well the training manual explains the reason for certain procedure steps, and to how well the manual familiarizes the operator with the general concepts of taking samples with the truck.

In discussions with truck personnel, training was said to be minimal in hands-on training prior to actual sampling operations. The sampling schedule necessary to meet the characterization demands makes extensive hands-on training costly. As a minimum, operators new to the truck should monitor an experienced operator for three complete sampling cycles. Three samplings should cover the most common interruptions likely to be encountered. As the new operator takes over the sampling, the experienced operator should monitor the new operator for three complete sampling cycles before certifying the operator for solo operation. 
A specific item in the training manual warrants a comment. The comment concerns the platform rotation and the interlocks which prevent rotation if the shielded receiver or drill rig is down, or the traversing platform is not centered. The impression from the training manual is that all rotation is prevented if these interlocks are active. The actual arrangement is that only fast rotation is locked out and slow rotation is still possible. The version in the manual would give a false sense of security that if the platform is rotating, even if just slowly, everything must be correctly positioned.

The operating procedure refers to a hydraulic bypass valve on Trucks 3 and 4. The training manuals do not include a discussion of this valve.

\subsection{MECHANICAL SYSTEMS/COMPONENTS FAILURE MODE ANALYSIS}

A Failure Mode, Effects, and Criticality Analysis (FMECA) was performed as part of the core sample truck evaluation. The scope of the analys is included the core sample truck with shielded receiver, drill rig, and grapple hoist, and how the design of the universal sampler assembly interacts with the components of the truck. The auxiliary equipment, such as the nitrogen trailer, electrical trailer, and exhauster system was not analyzed other than correct operation being critical to truck operation.

\section{Approach}

In coordination with the document review, core sampling was broken down into main tasks. Systems relevant to each task were identified and categorized as critical or non-critical for that specific task. Critical systems were reviewed for critical components. The function, failure effect, impending failure indication, and preventative measures of the critical components were analyzed. Non-critical systems were broken down into components and categorized further regarding the effect of their failure on standard operating procedures.

Only single failures are considered. Although failures of support structures can cause secondary failures of critical components, secondary failure analysis is beyond the scope of this task due to its complexity.

\section{Definitions}

Components were categorized as critical or one of three levels of noncritical. Critical components are those necessary for capturing a sample and retrieving and containerizing the sampler. The method for retrieving may not necessarily be the normal procedure. Retrieval may require pulling the entire drill string to retrieve the sampler.

Non-critical components are classified at the following three levels, representing a decrease in risks as well as a decrease in deviation from standard operating procedures:

- Non-critical 1 components are necessary for retrieving a sample without having to retrieve the drill string as well. 
- Non-critical 2 items are necessary for obtaining and retrieving a sample in accordance with the procedure without unanticipated deviation.

- Non-critical 3 components are easily replaced. These components include the disposable/single-use items, such as the samplers and pintle rods. Non-critical 3 items are also components that can function by other external means, such as mobile cranes.

\subsubsection{Core Sample Tasks}

Retrieving a sample from an underground storage tank involves several main tasks. This FMECA focuses only on tasks involving the operation of some part of the core sample truck. These main tasks are described below.

1. Platform positioning: Platform positioning includes the truck arriving at the tank farm, the hydraulic jacks leveling and stabilizing the truck, and the rotation/translation of the platform itself.

2. Riser preparation: The platform hoist is intended to be used for installing the riser equipment.

3. Drill string installation: Drill string installation is the insertion of the drill string into the tank.

4. Sampler insertion: Sampler insertion is the pushing or drilling of the core barrel and sampler into the waste to obtain a sample.

5. Sampler actuation: Sampler actuation is the closing of the sampler rotary valve to contain the sample.

6. Pintle rod retrieval: Pintle rod retrieval is removing the pintle rod from the drill string.

7. Sampler retrieval: Sampler retrieval is removing the sampler from the drill string.

8. Sampler containerization: Sampler containerization is putting the sampler in a transfer cask.

9. New sampler installation: New sampler installation is putting a new sampler in the already installed drill string.

Some tasks can be accomplished by more than one method. The operating procedure defines the way each task should be done, assuming that all systems are operating within specified parameters. Failures can either completely stop operations, or require some other method to complete a task (such as removing the drill string manually). Critical failures are those that stop operations without being able to obtain a sample. Non-critical failures are those that can or must be worked around and may result in the sample still being obtained. 
WHC-SD-WM-ER-537

Rev. 0

\subsubsection{Critical Systens}

From the core sample tasks, critical and non-critical systems relevant to each task were identified as shown in Table 1. The systems identified as critical for obtaining a sample are the truck itself, the hydraulics system, the drill rig, and the grapple hoist. The truck is critical for delivering the systems to the tank. The hydraulics are critical to leveling and stabilizing the truck for sampling operation, rotating and traversing the platform to position the drill rig over the penetration riser, and powering the drill rig. The drill rig is critical to pushing or drilling the drill string into the waste and filling the sampler. The grapple hoist is critical for actuating the sampler to capture a sample.

These four systems were deemed to be the only critical systems necessary for obtaining a retrievable sample. All other systems could be circumvented or failed component could be replaced to obtain the sample.

These four systems were further evaluated to identify the critical components. The critical mechanical and electrical components are identified in Table 2 .

In addition to the hardware critical systems, three items were made administratively critical by requiring the administrative shutdown of critical systems. These administrative controls, which are initiated by alarm signals that do not automatically shut down a system, are high and low instrument enclosure temperature alarms, a drill string purge gas high flow rate alarm, and a high drill string air/purge gas temperature alarm.

The high and low instrument enclosure temperatures result in poor operation of the control systems, and require the drill engine to be shut down manualiy. Without the drill engine, the hydraulics and drill rig cannot be operated. Both systems are critical to sampling. The environmental control system for the instrument enclosure is broken down into critical components in Table 2 .

The high flow rate alarm for the drill string purge gas can indicate a broken drill string. This alarm also requires the drill engine to be shut down. This alarm is 1 isted in Table 2 for completeness but was not applicable to being broken down into critical components.

The drill string/purge gas high/low temperature alarm indicates when the purge gas temperature is too low or too high. The alarm is intended to keep the sample from drying out or freezing. This alarm requires the drill clutch not to be engaged, which precludes any rotary drilling. For the harder waste types, rotary drilling is critical to obtaining a sample. This alarm is also listed but not broken down in Table 2 .

\subsubsection{Non-critical Systems}

System failures that interfere with the normal retrieval of a sampler are considered non-critical $l$ if those failures do not interfere with retrieving the drill string with the filled sampler still inside. Components that fall into this category are the sampler hoist in the shielded receiver 
and the remote latch unit. A large deviation from the standard operating procedure is necessary in the case of these failures.

System failures that do not interfere with the retrieval of a sampler are considered non-critical 2. For example, circumvention of a failure with the spray washer, ball valves on the changeout assembly and shielded receiver, and the nitrogen gas require only a partial deviation from the procedure. Partial deviation refers to steps that are optional for sampler retrieval at the discretion of the person-in-charge or cognizant engineer. As an example, pulling the sampler without the nitrogen gas would be a deviation from the procedure. The result would be some waste entering the drill string. cleaning the drill string with water is covered in the procedure.

Readily replaced components are considered non-critical 3 . These are components that are discarded after one use and have a supply of replacements readily available. A sampler or a pintle rod failure requires only that certain components be replaced. Certain sections of the operating procedure may need to be repeated but the general standard operating procedures are still followed.

Table 3 lists the non-critical 1 systems and their components. Failure would require large deviation from the standard procedures for recovery from the failed condition. Non-critical 2 and 3 systems and components are not within the scope of this review.

\subsubsection{Critical Components}

The failure of the critical components identified in Tables 2 and 3 is further analyzed below.

\section{Truck}

Failure of the truck was not broken down into components. Vehicle maintenance is common enough not to require a breakdown for this task. Regular maintenance and heeding warnings of impending problems are essential for reducing inconvenient failures.

\section{Hydraulics System Critical Components}

Mechanical

Mechanical components critical to the operation of the hydraulics system are the drill engine; the hydraulic pump; the torque converter; the flexible coupling and drive pulley that connect the engine to the pump; and the valves, fittings, and hoses that control the fluid direction.

\section{Electrical}

An electric starter is used to start the drill engine. No interlocks interfere with the control of the platform motion or hydraulic rams when operated from the control pendant. Therefore, the three interlocks that can 
kill power to the drill engine, and thus the hydraulics, can be bypassed and are not critical. These three interlocks are the drill RPM interlock, the purge gas below $30 \mathrm{scfm}$ interlock, and the downward ram force interlock.

\section{Control}

Correct operation of the control console is critical to operating the hydraulics system. The hydraulics can be controlled from the control console or the control pendant. The control select panel, however, is not critical to operating the hydraulics. The control select panel is used to select console or pendant control. When the control pendant is used, a switch on the control select panel determines whether the platform or drill rig ram hydraulics are active. Failure of either one of the two switches will allow operation of the platform and drill rig, either from the control console or the pendant.

Failure Effect

Failure of the drill engine, hydraulic pump or any part connecting the two components will result in no hydraulic pressure. Failure of one of the many valves interferes with the distribution of fluid and therefore, operation of one or more components which may or may not be critical in obtaining a sample. The same is true for a hose and fitting failures. Leakage from fittings and hoses is not critical but can lead to secondary failures.

Failure Reduction

To reduce failures of the hydraulic system, preventative maintenance is important. The hydraulic system will not function properly if there is particulate matter in the system. Hydraulic valves have fine orifices, springs, etc., that are extremely sensitive to contaminants. A small chip from a threaded fitting or piece of dirt can render a valve disfunctional and lock it in position, either open or closed. This can be successfully prevented by changing filters on a regular basis and using adequate filter media (200 micron).

The hydraulic system is subject to severe dynamic loading. Vibration from the engine, pressure spikes from opening and closing valves, and movement of the platform all act to load fittings in some manner. It is typically difficult, if not impossible, to get a system of this nature to be leak free.

There were several reports of leaks in the system, primarily at threaded fittings. Many of the fittings are SAE $37^{\circ}$ type which are the preferred type for hydraulic systems. Problems may arise due to over-tightening; therefore, the over-tightened fitting should be replaced.

If a leak in the hydraulic system is suspected to be due to an overtightened fitting, the fitting should be taken apart and the chamfered sealing surface should be inspected. If there is a noticeable groove on this surface, the fitting may have been over-tightened at some point and must be replaced. The fittings should be tightened using ordinary end wrenches without cheater bars or extensions. A thread locking compound can be used to stop the threads from loosening over time and use. The threads of the fittings must be properly cleaned for them to be effective. 
Pipe fittings are also used throughout the system. They are more prone to leakage than SAE fittings but can be used successfully with proper sealing compound.

The hydraulic system has many hoses and fittings. The leakage problem can be minimized by reducing the number of the hoses and fittings using a custom built manifold. These manifolds are ported and drilled for use with control valves and cartridge valves. The finished product would maintain the current hydraulic logic and would eliminate many potential leak points. Another benefit would be a more compact assembly without the confusing array of hoses throughout. The expense to have this made is estimated at approximately $\$ 5,000$.

Other components worth mentioning are the jacks used to raise the truck. After the truck is raised on these jacks, they are disconnected from the system by removing two quick disconnect fittings. This isolates the fluid in the jacks with no vent to the reservoir to compensate for thermal expansion which would not be a problem if the system is used only for short periods of time and then lowered off the jacks. If the system is left standing for an extended period of time, changing temperatures will change the fluid volume. Increase in temperature will cause a pressure increase which may be large enough to compromise the seals on the jacks. Seepage of fluid past the seals will then be observed.

To prevent the fluid leakage from the hydraulic jacks, an accumulator may be used to maintain constant pressure in the system. A single accumulator with a one-galion capacity should be sufficient. This could be installed on the retract side of the jack piping system in place of the \%-in. Nominal pipe thread plug (part number 90) which would allow the jacks to move slightly by displacing the fluid to the accumulator. A rough estimate of the amount of travel to expect is about $\frac{1}{2}$ in. over a $60^{\circ} \mathrm{F}$ temperature change. An important note to make here is that hydraulic jacks should not be relied on to support loads for extended periods of time. If practical, the truck should be lowered off the jacks when the truck is not in use for an extended period of time.

\section{Platform Rotation/Traverse System Critical Components}

Mechanical

Mechanical components critical to moving the platform are the bearing which allows the platform to rotate freely, the hydraul ic motor which drives the gear and pinion to rotate the platform, and the hydraulic system that powers the hydraulic motor and the traversing rams.

\section{Electrical}

Electrical components critical to positioning the platform are the rotation limit switches which limit the platform rotation and translation. The traverse center interlock, the shielded receiver up interlock, and the rams up interlock affect only the fast rotation; their failure does not interfere with the rotation of the platform, just the speed at which it travels. 
WHC-SD-WM-ER-537

Rev. 0

Control

Platform movement is controlled from the control console panel labeled "HYORAULIC CONTROLS," or the control pendant. Power to the control console and the hydraulic panel is critical to operating the controls which position the platform.

Failure Effect

Failure of any of these components will prevent the proper positioning of the truck or drill rig over the penetration riser, essentially stopping operations before they are started.

Failure Reduction

Preventative and regular maintenance will help reduce failures for these components. Regular greasing of the bearing and use of the lockdowns to avoid loading components not designed for loads experienced during transport will extend the functional life of the mechanical components.

Preventative and regular maintenance of the limit switches will reduce their failure from accumulation of debris and general wear. The switches should be cleaned, tested, and replaced on a regular basis to avoid untimely failures.

The control console switches critical to operating the platform positioning should also be tested and replaced as recommended by the manufacturer for harsh conditions.

\section{Drill Rig System Critical Components}

Mechanical

Mechanical components critical to the operation of the drill rig are the hydraulically operated chuck which locks the quill rod to the drive mechanism, the hydraulic rams which are the drive mechanism, the clutch which transmits rotation from the chuck to the quill rod for drilling, the hydraulic system which powers the rams and chuck, and the drill engine which powers the hydraulic system through the hydraulic pump.

\section{Electrical}

Three interlocks are critical to operating the engine of the drill rig: the rotational speed of the drill, the downward force on the hydraulic rams, and the purge gas flow rate. Drill string speed must exceed $2 \mathrm{rpm}$ before these interlocks can be energized. The exhauster override switch must be set to the Interlock position before it can cut off the electrical power to the drill engine and is, therefore, not a critical component. 
WHC-SD-WM-ER-537

Rev. 0

\section{Control}

The drill rig is controlled at the Longyear ${ }^{1}$ control console. The engine throttle along with the transmission control the speed of the drill. The ram flow control valves control the force and speed at which the drill rig moves up and down.

\section{Failure Effect}

Failure of the drill rig prior to initiating sampling requires only that the drill string be removed manually. Failure during sampling can result in an incomplete sample.

Failure Reduction

The maintenance schedule and operational guidelines recommended by the manufacturer of the drill rig should be used in the maintenance and operating procedures developed onsite. Sufficient spare parts should be readily available in case of failure.

Preventative and regular maintenance of the limit switches will reduce their failure from accumulation of debris and general wear. The switches should be cleaned, tested, and replaced on a regular basis to avoid untimely failures.

The control console switches critical to operating the platform positioning should also be tested and replaced as recommended by the manufacturer for harsh conditions.

Grapple Hoist System Critical Components

Mechanical

The grapple hoist system is critical to the capture and containment of a sample. The critical components of the grapple hoist system include the cable with the grapple on the end, the bearings in which the drum shaft turns, and the hoist motor and brake which turn and hold the drum. Additional components within the assembly, such as the counter which tracks the amount of cable let out and the guidance mechanisms, add to the smooth operation of the grapple hoist but are not critical. The grapple hoist system holds the piston of the sampler while the sampler body is lowered into the waste and pulls the pintle rod upward to actuate the sampler.

\section{Electrical}

The grapple hoist has a slack cable detector which cuts electrical power to the hoist motor. This detector is intended to prevent the cable from unspooling from the drum.

1

Longyear is a trademark of Longyear Canada Inc. 
Controls for the grapple hoist are on the sampler actuator panel which requires power to the control console as well as the panel itself. No interlocks interfere with the operation of the grapple hoist system because of two by-pass switches. Two by-pass switches allow for operation of the hoist during interlock activation: one allows the hoist to operate when the UP LIMIT SWITCH is activated: the other bypass allows the hoist to operate when the HYDRAULICS UP limit switch is activated.

\section{Failure Effect}

Failure of the grapple hoist system prior to initiating sampling will prevent sampling completely. Failure during the sampling process or prior to rotary valve actuation will prevent the sample from being captured and contained within the sampler. Failure of the grapple hoist to raise the pintle rod would require manual raising (about 150 lbf for pintle separation) of the hoist cable and/or pintle rod to clear the drill string for sampler removal. Failure of the grapple to release the pintle, either through failure of the hoist or grapple or the up limit bypass, would not directly interfere with retrieval of the sampler. The sampler could be released manually.

\section{Failure Reduction}

The grapple hoist motor should indicate an impending failure through abnormal noise or poor operation. The brake would also indicate problems by poor operation. These warnings should be heeded in a timely manner. Regular greasing of the bearing is important to prevent seizes, especially in the nitrogen environment of the grapple housing (Jenkins 1995). The grapple should be inspected for damage before use and the cable should be inspected regularly.

The slack detection switch can prevent the operation of the motor if it failed in the cut power state. Regular cleaning, testing, and replacement would reduce the risk of untimely failures.

The control console components for operating the grapple hoist should be tested and replaced according to the manufacturer's recommendations for a harsh environment.

\subsubsection{General Failure Reduction Actions}

A recurrent suggestion for reducing failures includes regular maintenance. A formal maintenance program should include the items discussed in Section 3.5.

In addition to the specific suggestions previously discussed, a more general suggestion was prompted by the review of the problem $10 \mathrm{~g}$ and procedures. A trouble shooting guide for in-field use would reduce some downtime by eliminating the easy to find, quick to fix problems first before more serious damage is done. A guide could also help decrease damage by identifying potential causes of malfunctions and provide steps to take to 
Rev. 0

reduce the risk of causing damage until the specific cause is identified. The FMECA done on this task as well as the problem $10 \mathrm{~g}$ are significant sources in developing such a guide.

\subsection{PREVENTATIVE MALNTEMANCE}

The following maintenance items should be included in a formal maintenance program. A comprehensive preventative maintenance program will go a long way in improving safety, reliability, and availability of these trucks.

As suggested in the stress analyses, some of the welds that have stresses close to allowables, and in some cases exceed the allowables, should be inspected on a regular basis. Fatigued welds can be identified and reinforced before a catastrophic failure.

Hydraulic items should undergo routine maintenance. Fittings should be checked for tightness. Actuator seals should be checked for leaks and repaired if required. Filters should be replaced regularly and fluid should be changed or run through a filter assembly for cleaning.

One very important maintenance item is to exercise the hydraulic components when they are not in use for extended periods. A good definition of an extended period is two months. If the hydraulics have not been used for two months, it is good practice to cycle or actuate the components. This means running actuators through the stroke two or three times, cycling directional control valves, and operating pumps and motors. This prevents seals and packing from taking a seat in position and keeps fresh fluid in valves and on seals.

As stated earlier, the interlock/limit switches should be cleaned, tested, and replaced on a regular basis according to the manufacturer's requirements for a harsh environment. 
Rev. 0

Table 1. Core Sampling Tasks and System Criticality.

\begin{tabular}{|c|c|c|c|c|c|}
\hline Task & $\begin{array}{c}\text { Main } \\
\text { System/Component }\end{array}$ & Critical & $\begin{array}{c}\text { Non- } \\
\text { Critical } 1\end{array}$ & $\begin{array}{c}\text { Non- } \\
\text { Critical } 2\end{array}$ & $\begin{array}{c}\text { Non- } \\
\text { Critical } 3\end{array}$ \\
\hline \multirow{3}{*}{$\begin{array}{l}\text { Platform } \\
\text { Positioning }\end{array}$} & Truck & $x$ & & & \\
\hline & Hydraul ics & $x$ & & & \\
\hline & $\begin{array}{l}\text { Platform } \\
\text { Rotation }\end{array}$ & $x$ & & & \\
\hline \multirow{2}{*}{$\begin{array}{l}\text { Riser } \\
\text { Preparation }\end{array}$} & Hydraul ics & & & & $x$ \\
\hline & Platform Hoist & & & & $x$ \\
\hline \multirow{2}{*}{$\begin{array}{l}\text { Drill string } \\
\text { Instal lation }\end{array}$} & Foot Clamp & & $x$ & & \\
\hline & Orill Rig & & $x$ & & \\
\hline \multirow{3}{*}{$\begin{array}{l}\text { Sampler } \\
\text { Insertion }\end{array}$} & Drill Rig & $x$ & & & \\
\hline & Grapple Hoist & $x$ & & & \\
\hline & Pintle Rod & & & & $x$ \\
\hline \multirow{3}{*}{$\begin{array}{l}\text { Sampler } \\
\text { Actuat ion }\end{array}$} & Grapple Hoist & $x$ & & & \\
\hline & Pintle Rod & & & & $x$ \\
\hline & Sampler & & & & $x$ \\
\hline \multirow{2}{*}{$\begin{array}{l}\text { Pintle Rod } \\
\text { Retrieval }\end{array}$} & Grapple Hoist & & $x$ & & \\
\hline & Hydraul ics & & & $x$ & \\
\hline \multirow{6}{*}{$\begin{array}{l}\text { Sampler } \\
\text { Retrieval }\end{array}$} & Hydraulics & & $x$ & & \\
\hline & Sampler Hoist & & $x$ & & \\
\hline & $\begin{array}{l}\text { Remote Latch } \\
\text { Unit }\end{array}$ & & $x$ & & \\
\hline & Nitrogen Gas & & & $x$ & \\
\hline & Ball Valves & & & $x$ & \\
\hline & Spray Washer & & & $x$ & \\
\hline \multirow{4}{*}{$\begin{array}{l}\text { Sampler } \\
\text { Containerization }\end{array}$} & Hydraul ics & & $x$ & & \\
\hline & $\begin{array}{l}\text { Renote Latch } \\
\text { Unit }\end{array}$ & & $x$ & & \\
\hline & Sampler Hoist & & $x$ & & \\
\hline & Ball Valves & & $x$ & & \\
\hline \multirow{4}{*}{$\begin{array}{l}\text { New Sampler } \\
\text { Installation }\end{array}$} & Sampler Hoist & & $x$ & & \\
\hline & Hydraul ics & & $x$ & & \\
\hline & Ball Valves & & & & \\
\hline & Nitrogen Gas & & & $x$ & \\
\hline
\end{tabular}


Table 2. Critical Systems.

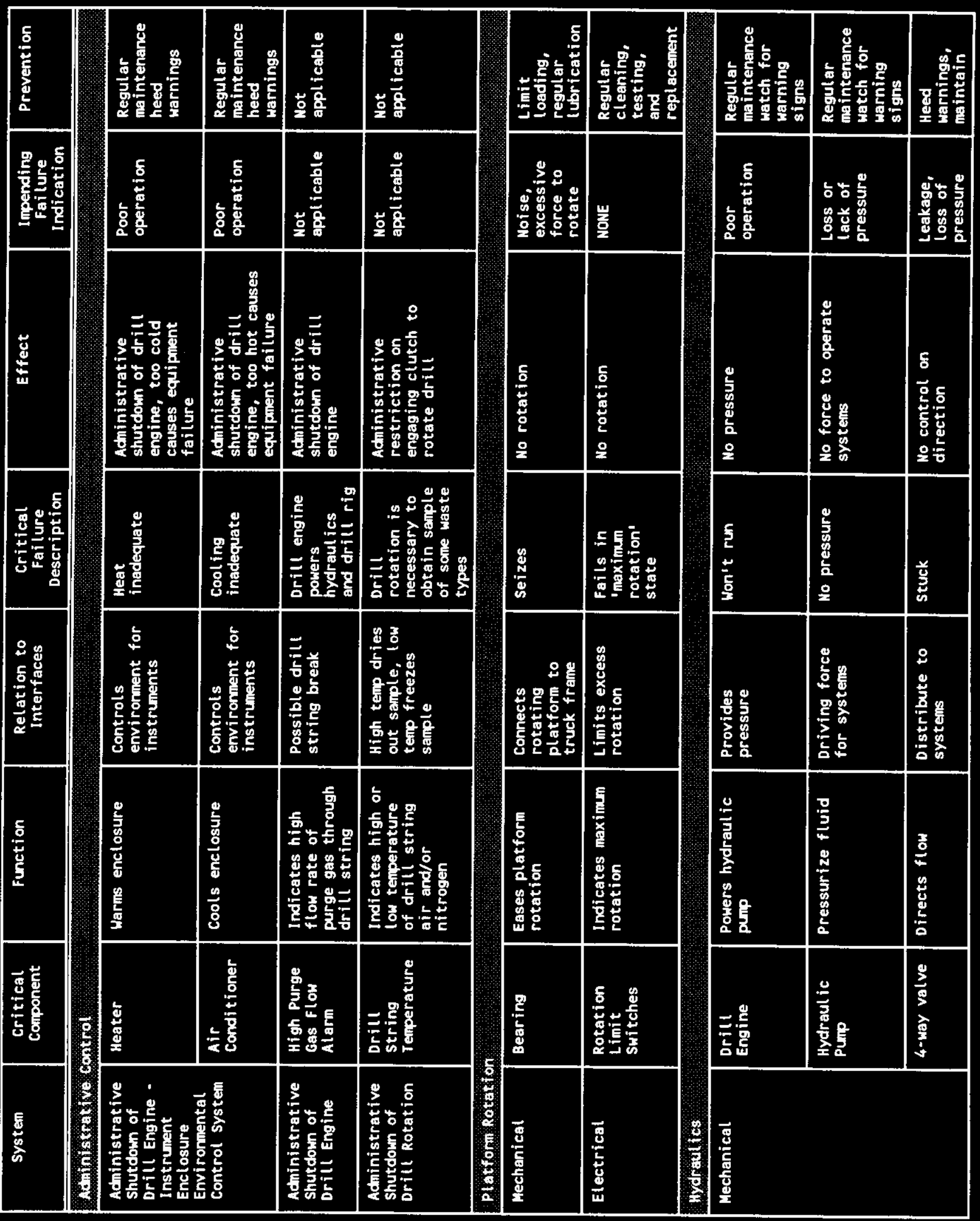




\begin{tabular}{|c|c|c|c|c|c|c|c|}
\hline System & $\begin{array}{l}\text { Critical } \\
\text { Component }\end{array}$ & Function & $\begin{array}{l}\text { Relation to } \\
\text { Interfaces }\end{array}$ & $\begin{array}{c}\text { Critical } \\
\text { Failure } \\
\text { Description }\end{array}$ & Effect & $\begin{array}{l}\text { Inpending } \\
\text { Fai lure } \\
\text { Indication }\end{array}$ & Prevention \\
\hline \multicolumn{8}{|l|}{ Drot 4 ald } \\
\hline \multirow[t]{3}{*}{ Mechanical } & $\begin{array}{l}\text { Drill } \\
\text { Engine }\end{array}$ & $\begin{array}{l}\text { Powers drill } \\
\text { rotation, } \\
\text { hydraul ics }\end{array}$ & $\begin{array}{l}\text { Driving force } \\
\text { for drilling }\end{array}$ & fails to run & $\begin{array}{l}\text { No push or rotary } \\
\text { drilling }\end{array}$ & $\begin{array}{l}\text { Poor } \\
\text { operation }\end{array}$ & $\begin{array}{l}\text { Regul ar } \\
\text { maintenance } \\
\text { watch for } \\
\text { warning } \\
\text { signs }\end{array}$ \\
\hline & Chuck & $\begin{array}{l}\text { Transfers } \\
\text { downtard force to } \\
\text { drill rod }\end{array}$ & Allows drilling & $\begin{array}{l}\text { Won't grip or } \\
\text { close }\end{array}$ & Drill rod slips & $\begin{array}{l}\text { sloppy } \\
\text { movenent }\end{array}$ & $\begin{array}{l}\text { Regular } \\
\text { maintenance }\end{array}$ \\
\hline & Clutch & $\begin{array}{l}\text { Transfer rotation } \\
\text { to drill rod }\end{array}$ & Rotary drilling & $\begin{array}{l}\text { Uon't engage } \\
\text { drill rod }\end{array}$ & No rotary cutting & $\begin{array}{l}\text { Sl oppy } \\
\text { movement }\end{array}$ & $\begin{array}{l}\text { Regular } \\
\text { maintenance }\end{array}$ \\
\hline \multirow[t]{3}{*}{ Electrical } & $\begin{array}{l}\text { RPH } \\
\text { Inter lock }\end{array}$ & $\begin{array}{l}\text { Cuts power to } \\
\text { drill engine }\end{array}$ & $\begin{array}{l}\text { Limits drill } \\
\text { rotation }\end{array}$ & $\begin{array}{l}\text { Fails in 'cut } \\
\text { power' state }\end{array}$ & $\begin{array}{l}\text { No drill engine } \\
\text { operation }\end{array}$ & NONE & $\begin{array}{l}\text { Clean, test } \\
\text { and replace } \\
\text { regularly }\end{array}$ \\
\hline & $\begin{array}{l}\text { Downward } \\
\text { Force } \\
\text { Interlock }\end{array}$ & $\begin{array}{l}\text { Cuts power to } \\
\text { dritl engine }\end{array}$ & $\begin{array}{l}\text { Limits downward } \\
\text { force on rans }\end{array}$ & $\begin{array}{l}\text { Fails in 'cut } \\
\text { power' state }\end{array}$ & $\begin{array}{l}\text { No drill engine } \\
\text { operation }\end{array}$ & MONE & $\begin{array}{l}\text { Clean, test } \\
\text { and replace } \\
\text { regularly }\end{array}$ \\
\hline & $\begin{array}{l}\text { Purge Gas } \\
\text { Flow } \\
\text { Interlock }\end{array}$ & $\begin{array}{l}\text { Cuts power to } \\
\text { drill engine }\end{array}$ & $\begin{array}{l}\text { Stops drill if } \\
\text { purge gas flow } \\
\text { drops below } \\
30 \text { scfm }\end{array}$ & $\begin{array}{l}\text { Fails in 'cut } \\
\text { power' state }\end{array}$ & $\begin{array}{l}\text { No drill engine } \\
\text { operation }\end{array}$ & NOWE & $\begin{array}{l}\text { Clean, test } \\
\text { and replace } \\
\text { regularly }\end{array}$ \\
\hline \multicolumn{8}{|l|}{ Grapple Hoist } \\
\hline \multirow[t]{2}{*}{ Mechanical } & Motor/Brake & $\begin{array}{l}\text { Drives and stops } \\
\text { rotation }\end{array}$ & $\begin{array}{l}\text { Powers hoist } \\
\text { and stops hoist }\end{array}$ & $\begin{array}{l}\text { Uon't run or } \\
\text { turn }\end{array}$ & No hoist operation & $\begin{array}{l}\text { Noise, } \\
\text { poor } \\
\text { operation }\end{array}$ & $\begin{array}{l}\text { Heed } \\
\text { warnings, } \\
\text { regular } \\
\text { maintenance }\end{array}$ \\
\hline & Grapple & Holds pintle & $\begin{array}{l}\text { Allows pintle } \\
\text { rod to activate } \\
\text { sampler }\end{array}$ & $\begin{array}{l}\text { Releases } \\
\text { pintle, won't } \\
\text { grasp pintle }\end{array}$ & $\begin{array}{l}\text { No sampler actuation, } \\
\text { no rod retrieved }\end{array}$ & Bent, worn & $\begin{array}{l}\text { Regular } \\
\text { inspection }\end{array}$ \\
\hline \multirow[t]{2}{*}{ Electrical } & $\begin{array}{l}\text { Pre-pint le } \\
\text { Release } \\
\text { Interlock } \\
\text { Bypass }\end{array}$ & $\begin{array}{l}\text { Allows hoist } \\
\text { motor to run when } \\
\text { interlock is } \\
\text { active }\end{array}$ & $\begin{array}{l}\text { Allows release } \\
\text { of pintle rod }\end{array}$ & $\begin{array}{l}\text { Fails to } \\
\text { allow motor } \\
\text { to run }\end{array}$ & No hoist operation & NONE & $\begin{array}{l}\text { Clean, } \\
\text { test, and } \\
\text { replace } \\
\text { regularty }\end{array}$ \\
\hline & $\begin{array}{l}\text { Slack cable } \\
\text { shutdown }\end{array}$ & $\begin{array}{l}\text { Stops hoist when } \\
\text { cable is slack }\end{array}$ & $\begin{array}{l}\text { Reduces 'bird } \\
\text { nesting' of } \\
\text { cable }\end{array}$ & $\begin{array}{l}\text { Fails to } \\
\text { allow motor } \\
\text { to run }\end{array}$ & No hoist operation & NONE & $\begin{array}{l}\text { Clean, } \\
\text { test, and } \\
\text { replace } \\
\text { regularly }\end{array}$ \\
\hline
\end{tabular}




\begin{tabular}{|c|c|c|c|c|c|c|c|}
\hline System & Component & Function & $\begin{array}{l}\text { Relation to } \\
\text { Interfaces }\end{array}$ & $\begin{array}{c}\text { Failure } \\
\text { Description }\end{array}$ & Effect & $\begin{array}{l}\text { Indication } \\
\text { of Pending } \\
\text { Failure }\end{array}$ & Prevention \\
\hline \multicolumn{8}{|c|}{ Sendiler tolst: } \\
\hline \multirow[t]{2}{*}{ Mechanical } & Motor & Operates hoist & & Fails to run & No hoist operation & $\begin{array}{l}\text { Noise, poor } \\
\text { operation }\end{array}$ & Heed warnings, \\
\hline & $\begin{array}{l}\text { Flanged } \\
\text { Bearing }\end{array}$ & $\begin{array}{l}\text { All ows free } \\
\text { rotation of } \\
\text { interlock assembly }\end{array}$ & & Seizure & $\begin{array}{l}\text { Inter lock } \\
\text { activation or no } \\
\text { slack avoidance }\end{array}$ & NONE & $\begin{array}{l}\text { Regular } \\
\text { maintenance } \\
\text { inspection }\end{array}$ \\
\hline Electrical & $\begin{array}{l}\text { Slack Cable } \\
\text { Inter lock } \\
\text { Suitch }\end{array}$ & $\begin{array}{l}\text { Cuts power to hoist } \\
\text { motor }\end{array}$ & $\begin{array}{l}\text { Prevents } \\
\text { unspool ing }\end{array}$ & $\begin{array}{l}\text { Fails in 'cut } \\
\text { poher' state }\end{array}$ & $\begin{array}{l}\text { No power to hoist } \\
\text { motor }\end{array}$ & NONE & $\begin{array}{l}\text { Clean, test, } \\
\text { and replace } \\
\text { regularly }\end{array}$ \\
\hline Control & $\begin{array}{l}\text { Panel } \\
\text { Switches }\end{array}$ & Activate components & & fail & $\begin{array}{l}\text { Wo activation of } \\
\text { components }\end{array}$ & MONE & $\begin{array}{l}\text { Clean, test } \\
\text { regularly }\end{array}$ \\
\hline \multicolumn{8}{|c|}{ shieldod Receliver Pltattorn } \\
\hline \multirow[t]{2}{*}{ Mechanical } & $\begin{array}{l}\text { Hydraul ic } \\
\text { Cyl inders }\end{array}$ & $\begin{array}{l}\text { Raise and lower } \\
\text { platform }\end{array}$ & $\begin{array}{l}\text { To connect } \\
\text { to changeout } \\
\text { assembly on } \\
\text { drill string }\end{array}$ & $\begin{array}{l}\text { Fail to } \\
\text { actuate }\end{array}$ & $\begin{array}{l}\text { Won't raise out of } \\
\text { way for plat form } \\
\text { rotat ion or lower } \\
\text { to connect }\end{array}$ & $\begin{array}{l}\text { Poor } \\
\text { operation, } \\
\text { hydraul ic } \\
\text { leaks }\end{array}$ & $\begin{array}{l}\text { Regular } \\
\text { maintenance }\end{array}$ \\
\hline & $\begin{array}{l}\text { Support } \\
\text { Frame }\end{array}$ & $\begin{array}{l}\text { Structure that } \\
\text { slides up and down }\end{array}$ & $\begin{array}{l}\text { Supports } \\
\text { sampler } \\
\text { hoist }\end{array}$ & $\begin{array}{l}\text { Jans due to } \\
\text { bent members }\end{array}$ & No movenent & $\begin{array}{l}\text { Deformation } \\
\text { of members }\end{array}$ & $\begin{array}{l}\text { Limit } \\
\text { transport and } \\
\text { other loading }\end{array}$ \\
\hline Electrical & NONE & & & & & & \\
\hline Control & $\begin{array}{l}\text { Hydraul ic } \\
\text { Control } \\
\text { Panel } \\
\text { Suitches }\end{array}$ & $\begin{array}{l}\text { Activate components } \\
\text { for operation }\end{array}$ & & Switches faíl & $\begin{array}{l}\text { No activation of } \\
\text { components }\end{array}$ & MONE & $\begin{array}{l}\text { Clean, test } \\
\text { regularly }\end{array}$ \\
\hline \multicolumn{8}{|c|}{ Remote Latch Unit } \\
\hline \multirow[t]{2}{*}{ Mechanical } & Motor & $\begin{array}{l}\text { Actuates grabbing } \\
\text { mechanism }\end{array}$ & & No operation & No grabbing & Noise & \\
\hline & Shaft & $\begin{array}{l}\text { Transfers motor } \\
\text { rotation to } \\
\text { grabbing mechanism }\end{array}$ & & $\begin{array}{l}\text { Breaks, cones } \\
\text { loose }\end{array}$ & No grabbing & NONE & \\
\hline Electrical & $\begin{array}{l}\text { High } \\
\text { Amperage } \\
\text { Cutoff }\end{array}$ & $\begin{array}{l}\text { Cut power when amps } \\
\text { too high }\end{array}$ & $\begin{array}{l}\text { Prevents } \\
\text { motor } \\
\text { burnout }\end{array}$ & $\begin{array}{l}\text { Fails in 'cut } \\
\text { power' state }\end{array}$ & No motor operation & NONE & $\begin{array}{l}\text { Clean, test, } \\
\text { and replace } \\
\text { regularly }\end{array}$ \\
\hline Control & Interlocks & $\begin{array}{l}\text { Prevents cycle } \\
\text { interruptions }\end{array}$ & & $\begin{array}{l}\text { Fails in 'no } \\
\text { interrupt' } \\
\text { state }\end{array}$ & Mo operation & NOME & \\
\hline
\end{tabular}


WHC-SO-WM-ER-537

Rev. 0

\subsection{REFERENCES}

AISC, 1989, Manual of Steel Construction, Allowable Stress Design, Ninth Edition, American Institute of Steel Construction, Chicago, Illinois.

Bogen, G. J., 1995, Rotary Mode Core Sampling Safety Items, Internal Memo to J. A. Harvey dated June 22, 1995, No. 75230-95-017, West inghouse Hanford Company, Richland, Washington.

Buck, F. R., 1994, Specification for Substructure for Phase \#2 100K Area, WHC-S-0329, Rev. O-A, Westinghouse Hanford Company, Richland, Washington.

Corbett, J. E., 1994, Rotary Mode Core Sampling Equipment List, WHC-SD-WM-SEL-032, Rev. 1, West inghouse Hanford Company, Richland, Washington.

DOE-RL, 1994, Rotary Mode Core Sampling Operational Readiness Review, DOE Letter No. 94-0CH-076, U.S. Department of Energy Richland Field Office, Richland, Washington.

DOE-RL, 1995, Rotary Mode Core Sampling Systems \#3 and \#4 - Final Readiness Assessment Report, DOE Letter No. 95-CHD-067, U.S. Department of Energy Richland Field office, Richland, Washington.

Farris, T. R., 1993, Development Criteria for the Rotary Mode, Universal Sampler \& Bit, and NPH Elimination Systems, WHC-SD-WM-CR-044, Rev. 1, Westinghouse Hanford Company, Richland, Washington.

Francis, P. M., 1994, Rotary Mode Sampling System Acquisition, WHC-SD-WM-ETP-029, Rev. 0, Westinghouse Hanford Company, Richland, Washington.

Jarecki, T. D., 1995, Operability Test Procedure for Rotary Mode Core Sampling System \#4, WHC-SD-WM-0TP-175, Rev. 0, Westinghouse Hanford Company, Richland, Washington.

Jenkins, W. W., 1995, Rotary Mode Core Sample System Availability Improvements, WHC-SD-WM-ER-415, Rev. 0, West inghouse Hanford Company, Richland, Washington.

Koehler, D. A., 1992, Grapple Hoist Mounting Support Assembly (Truck \#2) Stress Evaluation, (Internal Memo CSA:DAK:ggb:92/10 to J. C. Mast (WHC), November 18), Westinghouse Hanford Company, Richland, Washington.

Meyers, K. E., 1995, Completion of Rotary Mode Core Sampling Plant Readiness Team Activities, Internal Memo to R. Ni, dated June 30, 1995, Westinghouse Hanford Company, Richland, Washington.

Milliken, N. J., 1995, Safety Analys is for Push-Mode and Rotary-Mode Core Sampling, WHC-SD-WM-SARR-031, Rev. 2, Westinghouse Hanford Company, Richl and, Washington. 
Rezvani, M. A., 1992, Sampler Hoist Housing Assembly Stress Evaluation, WHC-SD-WM-ER-141, Rev. 0, Westinghouse Hanford Company, Richland, Washington.

Rezvani, M. A., 1993, Grapple Hoist Housing Assembly Stress Analysis and Evaluation, WHC-SD-WM-ANAL-023, Rev. 0, West inghouse Hanford Company, Richland, Washington.

Smalley, J. L., 1993, Specification for Rotary Mode Core Sample Truck, WHC-S-0239, Rev. 0, Westinghouse Hanford Company, Richland, Washington.

Vollert, F. R. and T. S. Hundal, 1995, Structural and Stress Analysis, Shield Receiver Lifting Frame and Jack Assemblies, Core Sampler Trucks \#3 and \#4, WHC-SD-WM-ER-469, Rev. O (Draft), West inghouse Hanford Company, Richland, Washington.

WHC, 1994, TWRS Support Operations Training: Rotary Mode Core Sample Truck Course 350071 - Student Manua7, Rev 0, Westinghouse Hanford Company, Richl and, Washington.

WHC, 1995, Perform Rotary Core Sampling of Ferrocyanide, Organic, Organic/Ferrocyanide Watch-List Waste Storage Tanks, Tank Farm Plant Operating Procedure T0-080-056, Rev A-0 (Release Date 8/29/95), Westinghouse Hanford Company, Richland, Washington.

Ziada, H. H., 1992, Drill Head Service Platform Assembly (Truck \#2) Stress Evaluation, (Internal Memo CSA:HHZ:ggb:92/8 to R. J. B1 anchard (WHC), August 18), Westinghouse Hanford Company, Richland, Washington.

Ziada, H. H., 1995, Stress Analysis of Jacks, Frame and Bearing Connections, and Drill Rod for Core Sampler Truck \#2, WHC-SD-WM-ER-392, Rev. 0, Westinghouse Hanford Company, Richland, Washington.

Ziada, H. H., 1994, Stress Analysis for the Cable Pulley Shaft of the Grapple Hoist Assemb7y, WHC-SD-WM-ANAL-027, Rev. 0, West inghouse Hanford Company, Richland, Washington.

Ziada, H. H., 1994a, Stress Analysis of Core Sampler Truck Number 2 Platform2,000 7 bf Crane Lift Capacity, WHC-SD-WM-ER-380, Rev. 0, Westinghouse Hanford Company, Richland, Washington.

Ziada, H. H., 1994b, Rollover Analysis of Rotary Mode Core Sampler Truck \#2, WHC-SD-WM-ER-391, Rev. 0, Westinghouse Hanford Company, Richland, Washington.

Ziada, H. H., 1994c, Stress Analysis of Shielded Receiver Lifting Frame for Core Sampler Truck \#2, WHC-SD-WM-ER-390, Rev. 1, West inghouse Hanford Company, Richland, Washington.

Ziada, H. H., 1994d, Dynamic and Buckling Analysis for Rotary Mode Drill String for Core Sampling, Internal Memo, CSA:HHZ:ggb:94/3, dated January 6, 1994 to T. R. Farris, Westinghouse Hanford Company, Richland, Washington. 
WHC-SD-WM-ER-537

Rev. 0

Ziada, H. H., 1995, Axial Failure Load Estimates for Push Mode Drill String, DSI dated October 18, 1995 to L. F. Ermold et al., Westinghouse Hanford Company, Richland, Washington.

Department of Defense, MIL-STD-1629A, Procedures for Performing a Failure Mode, Effects, and Criticality Analysis, November 1980 
WHC-SD-WM-ER-537

Rev. 0

\section{APPENDIX A}

DESIEN \& OPERATIONS OF CORE SAMPLING TRUCKS 
WHC-SD-WM-ER-537

Rev. 0

\section{DESIGN \& OPERATIONS OF TRUCKS}

In genera], two types of waste exist in the underground waste tanks: sludge and hard salt cake. The core sampling trucks provide means to take full depth samples of the tank waste. For tanks with waste in the sludge form, the sampler is pushed through the waste using hydraulic pressure. The push mode penetration may be difficult, however, if the hard salt cake exists. In that case, a sample is taken by rotary mode operation which involves drilling into the waste. All trucks except Truck 1 can be operated in both modes. The rotary mode operation is not permitted for the 25 tanks that contain flammable gases.

It has been experimentally established that exothermic reaction in ferrocyanide/nitrate mixtures may start at $180{ }^{\circ} \mathrm{C}$ (Kirch 1991). Therefore, the sampling operation must not increase the waste temperature above this temperature. Studies have been performed to show that in the push mode, the waste temperature will remain below $180{ }^{\circ} \mathrm{C}$ in the hottest tank. During rotary mode sampling, a nitrogen purge is required to cool the drill bit to conservatively maintain its temperature below $150{ }^{\circ} \mathrm{C}$. During rotary mode operation, an exhauster system is required for tanks that do not have their own active ventilation system to maintain a negative pressure within the tank against the addition of nitrogen purge gas.

\section{A.1 DESIGN FEATURES}

Although the trucks are equipped with many systems and equipment to perform sampling operations, the two main components are the dri11 unit and the shielded receiver assembly. As the name implies, the drill unit is used to obtain a core sample in a sampler assembly. After the sample is obtained, the sampler is raised into the shielded receiver and transferred to a transfer cask and then to the laboratory for waste characterization. A schematic view of the truck is shown in Figure $A-1$.

To perform sampling, the truck must be positioned for the drill and the sampler to be lowered into the tank penetration. A sampler is inserted into the drill string core barrel and the drill string is attached to the core barrel. The drill string is lowered into the tank and additional sections of drill string are attached until the sampler is just above the waste surface. The drill string is either pushed or rotated into the waste to obtain the sample. In the rotary mode, a nitrogen purge is required to cool the drill bit.

The drill string is detached from the drill unit after the core sample is obtained. The shielded receiver is then placed over the drill string and the sample is raised into the shielded receiver. From the shielded receiver, the sample is transferred into a transfer cask before it is sent to a laboratory for characterization.

The process of sampling as described above requires the drill unit and the shielded receiver to be mounted on a platform that can be rotated to position them alternately over the tank penetration and the transfer cask. 
WHC-SD-WM-ER-537

Rev. 0

The drill unit and the shielded receiver must be able to move horizontally to position them directly over the penetration adapter attached to the tank penetration. below.

The design features of the main components are described in the sections

\section{A.1.1 Truck}

The truck itself is an F-800 (F-700 for Truck 2) diesel engine, conventional cab, single-axle, truck manufactured by the Ford Motor Company. A lower frame is supported full length on a 2-in. thick wood spacer that sits on top of the truck chassis longitudinal members. The lower frame is attached to the chassis and held on spacers with six welded and bolted clip angle connections. A stationary platform and a rotary platform, shown in Figure A2, are mounted on the lower frame. No sampling equipment is installed on the stationary platform.

The rotary platform assembly consists of a lower bearing mount plate attached to the lower frame by 12 bolts, a spacer bolted to the bearing mount plate, a bearing attached to the bearing plate by 18 bolts, and the upper bearing plate attached to the platform by 8 bolts. The platform is rotated by a gear-pinion arrangement driven by a hydraulic motor. With the drill head at the rear-center, the platform can rotate $200^{\circ}$ in either direction. Any rotation greater than this is automatically stopped by limit switches.

The rotary platform houses an instrumentation cabinet, a control console, purge gas assembly, shielded receiver assembly, drill head and grapple hoist assembly, Longyear gasoline powered engine and torque converter, and a 2-ton stationary crane. The Longyear engine provides power to rotate the drill head and also drives the pump which pressurizes the truck's hydraulic system. The hydraulic system powers the rotary and traversing platforms, the leveling and stabilizing jacks, and the hydraulic rams used for lowering and raising the drill head and the shielded receiver.

The control console support frame and the stationary crane are bolted to the rotary platform. The drill head, Longyear engine, grapple hoist assembly and the shielded receiver are supported by frames which can slide on the slide plates bolted to the rotary platform. Hydraulic rams are activated to move the drill head and the shielded receiver forward and backward on the slide plates. This motion combined with the rotary motion of the platform is used to center the drill string within the tank penetration adaptor assembly. For small rotations, when rotation of the rotary platform is not practical, the drili head assembly can be moved sideways by activating hydraulic rams which provide slew motion.

The trucks are equipped with one front, and two center and rear jacks which are deployed to stabilize and level the truck before the sampling operation begins. The center jacks are for truck stabilization only and are lowered only after the truck is leveled.

1 Longyear is a trademark of Longyear Canada Inc. 
Rev. 0

\section{A.1.2 Sampler}

The sampler assembly consists of a sampler body, rotary valve, molded seal, piston, 0-ring, quadralatch, a spring and pull block with cables for closing the rotary valve, and a pintle rod (see figure A-3). The sampler assembly is inserted into a core barrel at the bottom of the drill string. The entire sampler assembly is used only for one sampling operation and is not reused.

The sampler body is made of stainless steel and is used to hold the sample. The rotary valve body is threaded onto the bottom end of the sampler body. The rotary valve and valve stop assembly reside in the valve body which has a molded seal assembly insert at the bottom. The molded seal forms a seal between the valve body and the drill string core barrel and prevents the waste from entering into the drill string core barrel. An 0-ring creates a seal between the piston and the sampler body. At the start of sampling, the piston is at the bottom of the sampler in the valve body. When the drill string is pushed down with the piston held stationary by the pintle rod and grapple hoist, the 0-ring seal creates a suction which draws the tank waste into the sampler. When the sample stroke is complete, the 0-ring and piston seal the upper part of the sampler body and the rotary valve is closed to seal the bottom of the sampler.

The top of the piston is connected to the pintle rod by a shear pin. The pintle rod has another insert pin slightly above the shear pin. This pin is assembled flush on one side and extends on the other side of the pintle rod. The pintle rod extends the full length of the sampler and has a cone shaped pintle at the top. The grapple is lowered or raised by an electrically operated hoist at the top of the drill unit and latches onto the pintle.

The sample is taken by pushing the drill string core barrel into the waste in the push mode or by drilling into the waste in the rotary mode. Upon completion of the sampling stroke, the grapple is raised, raising the pintle rod. The insert pin on the pintle rod activates the trigger mechanism, releasing the compressed spring which pushes up the pull block. The pull block pulls the two cables attached to the rotary valve. This action closes the rotary valve and the waste sample is retained in the sampler. The grapple continues to raise the pintle rod which causes the shear pin to break releasing the pintle rod from the piston. The grapple raises the pintle rod above the drill rod adaptor, the drill string is separated from the drill rod adaptor, and the pintle rod is released into container and discarded.

The top of the sampler body has a quadralatch assembiy. This assembly is used to retrieve the sampler into the shielded receiver. The remote latch unit attached to the sampler hoist is lowered to the sampler and activated to close on the quadralatch. The remote latch unit is then raised by the hoist to raise the sampler into the shielded receiver.

\section{A.1.3 Drill String}

The drill string consists of sections of $2 \frac{1}{2}-i n$. carbon steel pipe which come in various lengths. The core barrel containing the sampler is attached to the drill string which acts as a travel way for the sampler, grapple unit, 
and remote latch unit. The drill string also transfers the downward force to the drill bit and also the rotation if the sampling mode is rotary.

Decontamination of the drill string for reuse is not cost effective. Once removed from the tank penetration, the drill string sections are discarded.

\section{A.1.4 Drill Unit}

The Longyear drill unit consists of a gasoline engine, hydraulic pump, grapple hoist, quill rod, chuck, and hydraul ic system. The rig is powered by the Longyear engine and applies downward thrust and rotary motion to the drill string. The rotation of the drill string is not engaged in push mode operation.

The drill rig is supported by a drill head service platform which has five legs bolted to the rotary $p$ latform and an end-plate bolted to the engine housing. The service platform also supports the instrument cabinet, purge gas assembily, and the grapple hoist assembly.

The grapple hoist assembly consists of many parts including grapple, motor, drum, swivel, cable and pulleys, cable length counter. The grapple latches onto the pintle of the sampler assembly and the grapple hoist keeps the sampler's piston stationary during sampling. The grapple hoist also pulls the pintle rod to close the rotary valve at the completion of the sampling stroke and removes the pintle rod to prepare the sampler for retrieval into the shielded receiver. The grapple hoist is powered by the motor which turns the drum located in the grapple hoist box at the top of the drill unit. The grapple hoist cable spools off the drum over guide pulleys, runs down through the bellows assembly, the quill rod, and the drill string. The bellows are part of the pressurized nitrogen purge flow path to the drill string and compensates for the vertical travel of the drill rig. A swivel connects the bellows to the quill rod to prevent the rotary motion of the quill rod from twisting the bellows. The quill rod is a section of pipe with an adaptor at the bottom to connect the drill string. The drill unit's hydraulically actuated chuck locks onto the quill rod for transferring the drill rotation and downward translation. The bellows, quill rod, and connected drill string provide the travel way for the grapple and the nitrogen purge gas.

The drill unit components are powered by the hydraulic system. The hydraulic pump is driven by the Longyear gasoline engine. Hydraulic actuators and motors are used to power the drill string rotation and vertical travel, the vertical positioning of the shielded receiver, and the service platform rotation, translation, and slew. The truck's leveling and stabilizing jacks are also hydraulically actuated and use a remote connection to attach to the truck's hydraulic system.

\section{A.1.5 Shielded Receiver Assembly}

The shielded receiver is a long steel tube lined on the inside with 1 in. of lead and provides interim sample shielding. The shielded receiver is pressurized with nitrogen when the sampler is raised into it. Two hydraulic cylinders raise or lower the receiver as required. 
A remote latch unit (RLU) which resides in the receiver is used to retrieve samplers and to install new samplers into the drill string core barrel. The RLU, shown in Figure A-4, latches on to the quadralatch unit attached to the sampler and looks from outside like a steel bar 1.5 in. in diameter. Its bottom end is machined to form an inverted cone to compress the fingers of the quadralatch and it houses an electric motor, a coupling which connects the motor and a drive rod, and a release plunger. When the RLU is lowered onto the quadralatch, the quadralatch fingers sit in the recess in the inverted cone of the RLU. The RLU can then be raised by the shielded receiver hoist to bring the sampler into the shielded receiver. To release the sampler into the cask, the release plunger is driven down by the RLU motor. This squeezes the quadralatch fingers which frees the quadra latch and the sampler from the RLU.

The RLU is also used to put a new sampler into the shielded receiver and to lower the sampler into the drill string for further sampling.

\section{A.1.6 Nitrogen Purge System}

Nitrogen purge is required when operating in the rotary mode. Nitrogen gas is used to cool the drill bit and to aid in chip removal during drilling. Nitrogen gas is also used in both rotary and push modes of operation to balance the hydrostatic head of the waste to prevent waste from being pushed into the drill string during sampler removal and installation.

Nitrogen gas to balance the hydrostatic head is supplied through the shielded receiver until the isolation valves are closed and the pressure can be supplied through the change-out assembly alone. Nitrogen gas through the shielded receiver also helps prevent contaminants from entering the shielded receiver.

\section{A.2 SAMPLING PROCESS}

As stated earlier, the trucks can be operated in either rotary mode or push mode. The initial choice is determined by the anticipated waste type: push mode for sludge and soft saltcake, rotary mode for medium and hard saltcake. Once the operator finds that sampling can no longer proceed in the push mode, the truck is prepared for the use in the rotary mode. modes.

The following sections very briefly describe the operation in the two

\section{A.2.1 Push Mode}

First, the sampler is inserted into the core barrel and the drill string is attached to the core barrel. The drill string is then lowered into the tank and the additional lengths of drill string are attached as determined in the work plan. When the sampler is just above the waste surface, the drill string is attached to the quill rod. Rotation of the drill string is prevented by disengaging the drill clutch. 
The grapple is lowered to latch onto the pintle. The hydraulic ram is then activated to apply downward force on the quill rod and in turn to the drill string to obtain a sample. Upon completion of the sampling stroke, the grapple is raised up which activates the rotary valve closure mechanism when the pin on the pintle rod releases the spring directly below the pull block. The upward movement of the pull block pulls the cable attached to the rotary valve and closes the valve. Further upward movement of the grapple causes the shear pin connecting the piston and the pintle rod to break. The waste sample is retained in the sampler body between the piston and the rotary valve. The pintle rod is raised above the quill rod adaptor. The drill string is disconnected from the quill rod and both are capped. The platform is rotated so the quill rod adaptor can be connected to a pintle rod container. The pintle rod is released into the container and the quill rod is disconnected and capped again. The platform is rotated again to position the shielded receiver over the drill string.

Before the shielded receiver is positioned over the drill string, the sampler change-out assembly is installed. Nitrogen is supplied to the drill string to prevent waste from entering the core barrel when the sampler is being removed. The grapple is raised to remove the pintle rod which is deposited in a special container. The platform is rotated to bring the shielded receiver over the drill string. The shielded receiver is connected to the change-out assembly and is pressurized with nitrogen. The isolation valve on the sampler change-out assembly is opened. The remote latch unit is lowered and attached to the sampler quadra latch. The sampler is raised into the receiver and the isolation valve on the sampler change-out assembly is closed. The shielded receiver is then depressurized. The ball valve on the shielded receiver is closed, the shielded receiver is unlatched from the change-out assembly and raised up. The platform is then rotated to position the receiver over the empty transfer cask, the ball valve is opened, and the sampler is lowered into the transfer cask and released by the remote latch unit.

To insert an empty sampler for further sampling, the shielded receiver is positioned over an empty sampler, the ball valve is opened, the remote latching unit is lowered and attached to the empty sampler, and the sampler is then raised into the shielded receiver. The ball valve is closed, the shielded receiver is unlatched, and the platform is rotated to position the shielded receiver over the drill string. The shielded receiver is then connected to the sampler change-out assembly and pressurized, the ball valves on the shielded receiver and the change-out assembly are opened, and the remote latch unit and the sampler are lowered into the drill string low enough to latch into the core barrel. The remote latch unit is then disconnected and raised away from the sampler. The isolation valve on the sampler change-out assembly is closed and the shielded receiver is depressurized. The ball valve on the shielded receiver is then closed and the shielded receiver moved away from the sampler change-out assembly. The drill string is depressurized and the sampler change-out assembly is disconnected. Another section of drill string is added and the next sample is taken.

\section{A.2.2 Rotary Mode}

The sampling operation and the sample recovery process essentially remains the same as described in Section A.2.1 except that the nitrogen system 
Rev. 0

must be activated in the rotary mode to cool the drill bit. Also, if the tank does not have an active ventilation system, a portable exhauster must be used.

The safety analysis requires the drill bit temperature not to exceed $150{ }^{\circ} \mathrm{C}$. However, the drill bit temperature is not directly measured. By limiting the drill rotation to $55 \mathrm{rpm}$ and the down force on the drill string to $11701 \mathrm{bf}$ while maintaining at least 30 standard cubic feet per minute flow of nitrogen through the drill string, the drill bit temperature will not exceed the above limit. An alarm will be activated if any of these conditions are not met. If the operator is unable to correct the problem within a brief period of time, the truck will automatically shutdown due to electrical power to the truck being cut, killing the drill engine.

The operating procedure allows the truck to be operated in the rotary mode without nitrogen purge at the discretion of the person-in-charge. It, however, restricts the speed and duration of the drill bit rotation, and time between drillings to limit drill bit temperature. 
WHC-SD-WM-ER-537

Rev. 0

Figure A-1. Truck Schematic.

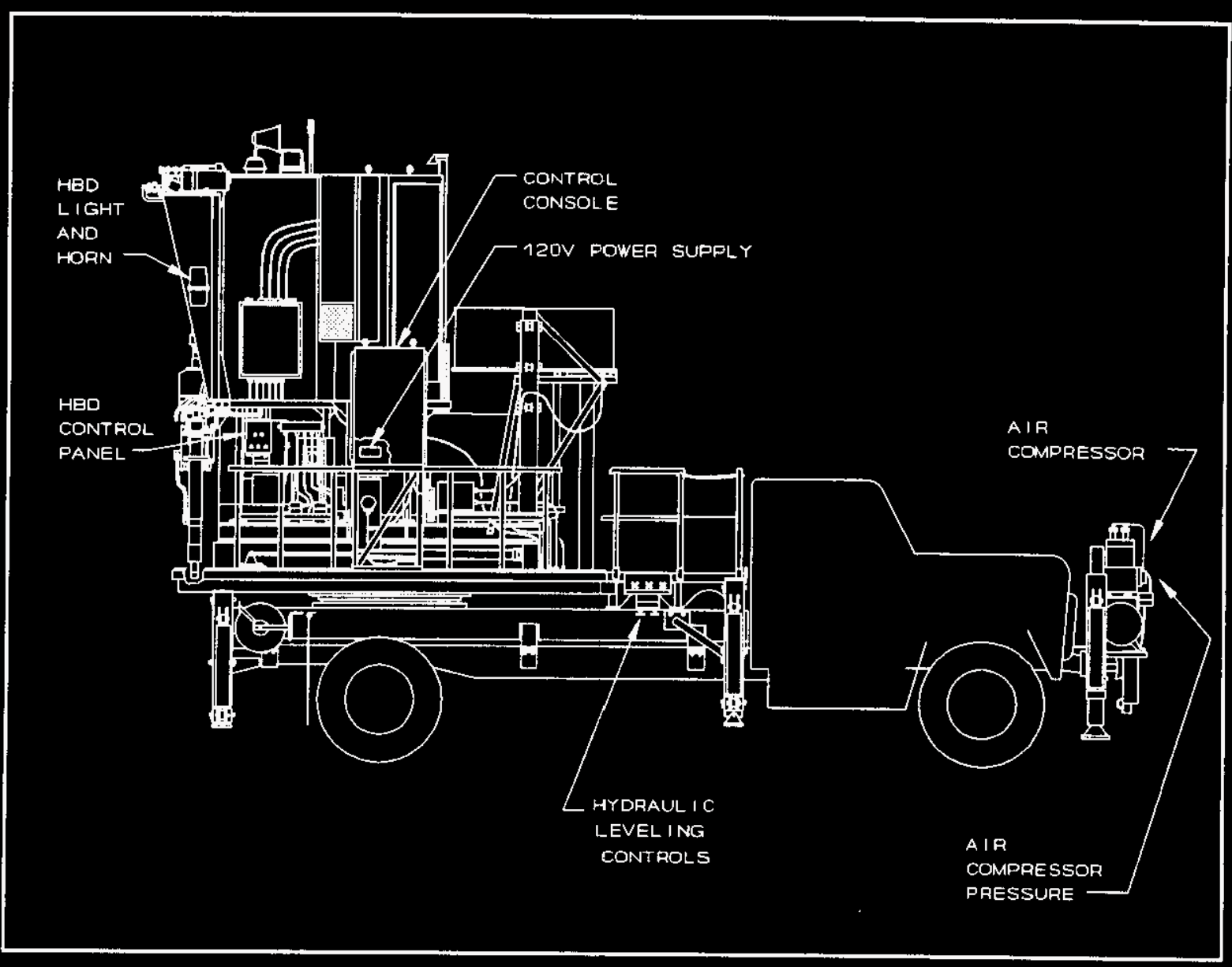


WHC-SD-WM-ER-537

Rev. 0

Figure A-2. RMCS Platform (Driver Side).

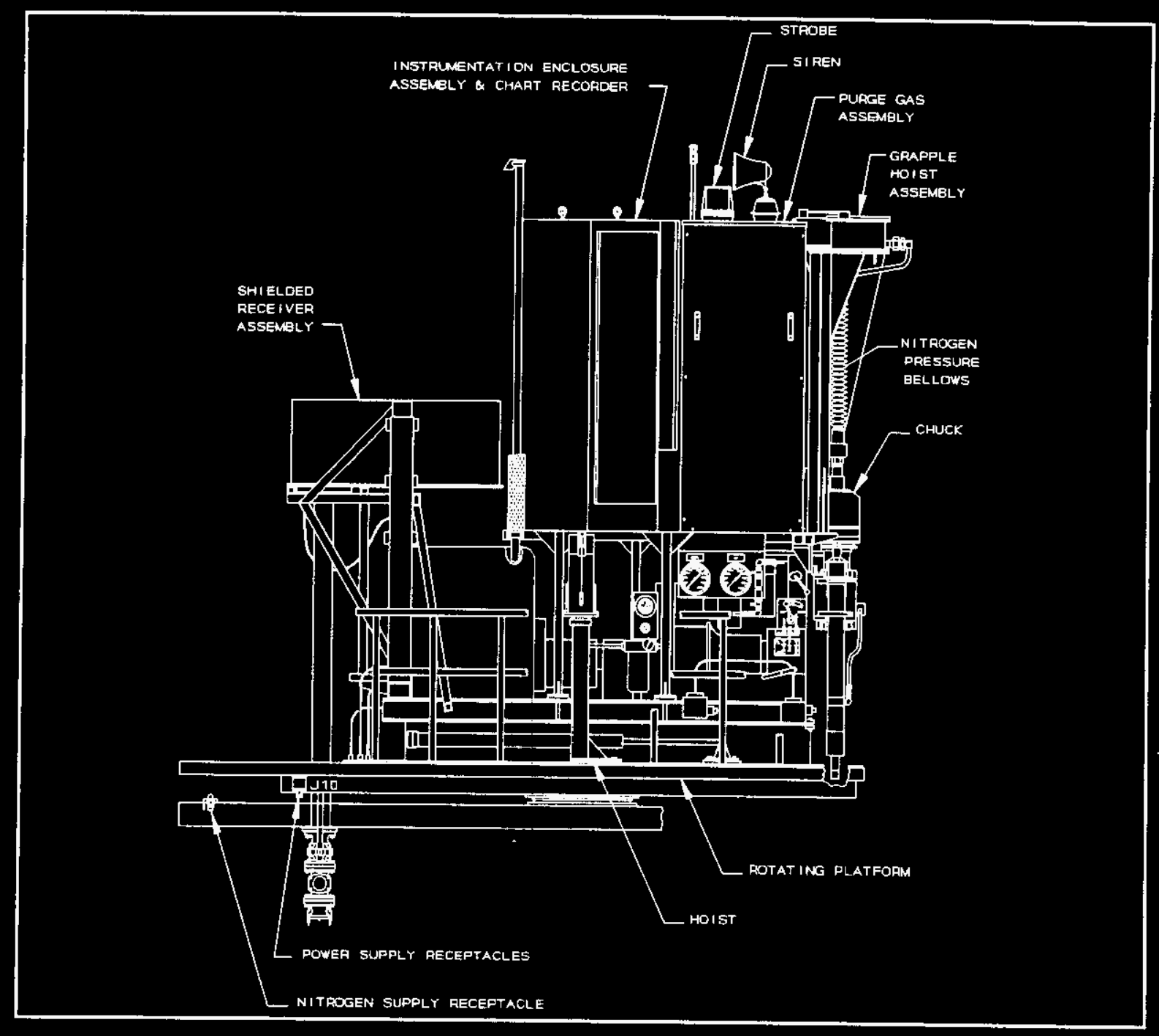


WHC-SD-WM-ER-537

Rev. 0

Figure A-3. Sampler Assembly

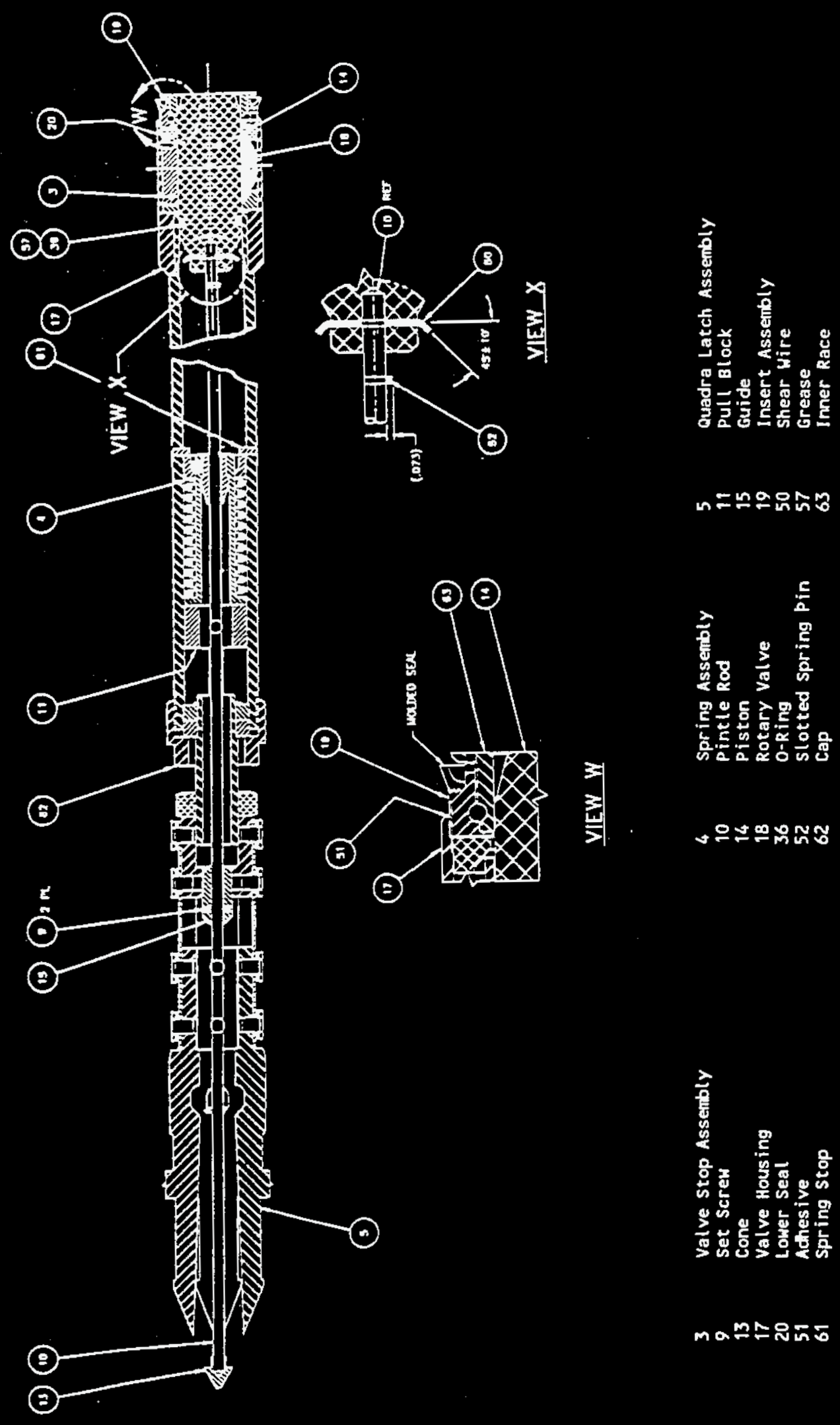


WHC-SD-WM-ER-537
Rev. 0

Figure A-4. Remote Latch Unit

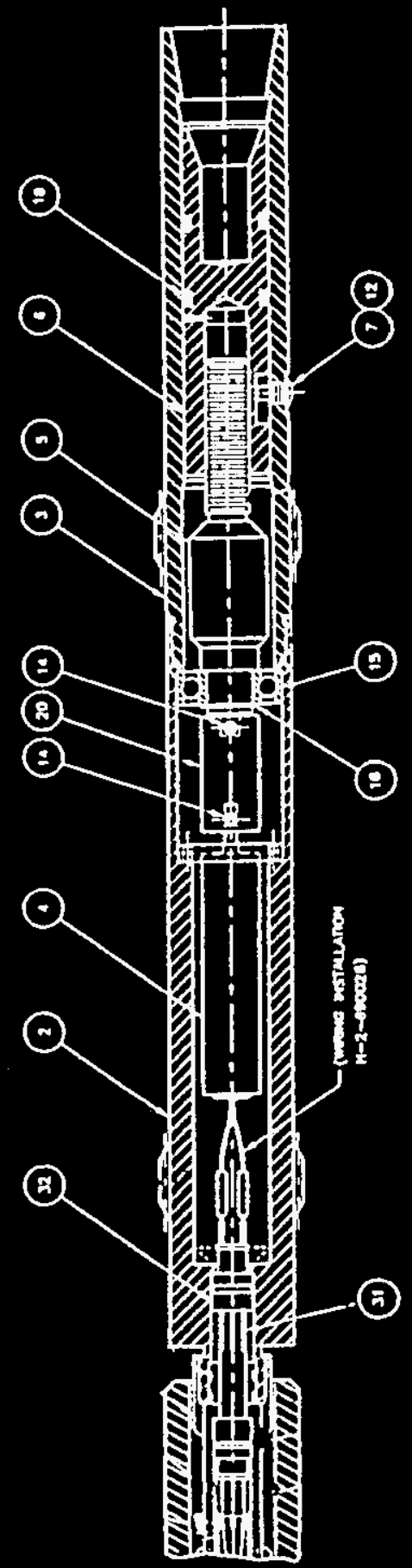

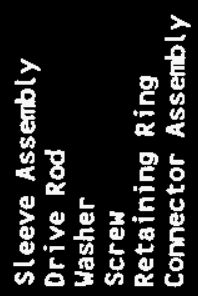

$\operatorname{mun} \pm \div \%$

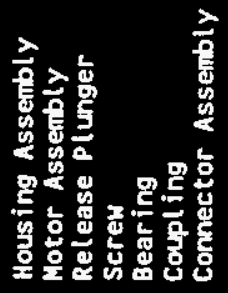

N+0ำกิก 


\section{DISTRIBUTION SHEET}

\begin{tabular}{|c|c|c|c|c|c|}
\hline To & \multirow{2}{*}{\multicolumn{3}{|c|}{$\begin{array}{l}\text { From } \\
\text { ICF KH Mechanical Engineering }\end{array}$}} & \multicolumn{2}{|l|}{ Page 1 of 1} \\
\hline $\begin{array}{l}\text { Characterization Equipment } \\
\text { Engineering }\end{array}$ & & & & \multicolumn{2}{|c|}{ Date $02 / 28 / 96$} \\
\hline \multicolumn{4}{|l|}{ Project Title/Work Order } & \multicolumn{2}{|c|}{ EDT No. 615123} \\
\hline \multicolumn{4}{|c|}{$\begin{array}{l}\text { Design/Operations Review of Core Sampling Trucks and Associated } \\
\text { Equipment }\end{array}$} & \multicolumn{2}{|l|}{ ECN No. $\quad N / A$} \\
\hline Name & MSIN & $\begin{array}{l}\text { Text } \\
\text { With All } \\
\text { Attach. }\end{array}$ & Text Only & $\begin{array}{l}\text { Attach./ } \\
\text { Appendix } \\
\text { Only }\end{array}$ & $\begin{array}{l}\text { EDT/ECN } \\
\text { Only }\end{array}$ \\
\hline
\end{tabular}
A. W. Bjorkedal
V. R. Ender lin
D. W. Hamilton
L. J. Julyk
B. M. Koons
J. L. Smalley
G. P. Janicek
H. P. Shrivastava
Central Files (2)

B4-40

H5-70

S7-12

H5-56

S3-10

S7-12

S7-12

B4-40

A3-88

$X$
$X$
$X$
$X$
$X$
$X$
$X$
$X$
$X$

